Provided for non-commercial research and education use. Not for reproduction, distribution or commercial use.

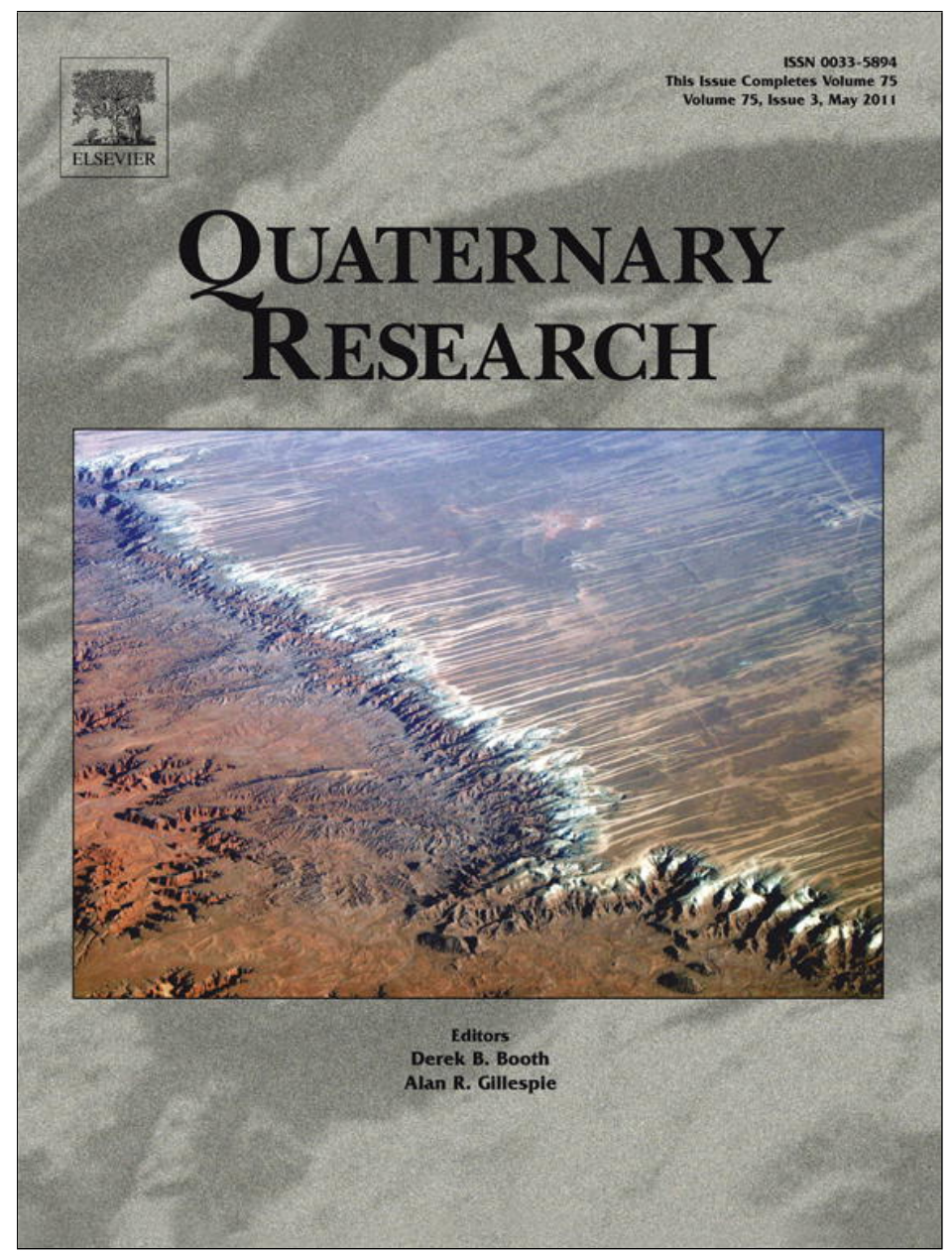

This article appeared in a journal published by Elsevier. The attached copy is furnished to the author for internal non-commercial research and education use, including for instruction at the authors institution and sharing with colleagues.

Other uses, including reproduction and distribution, or selling or licensing copies, or posting to personal, institutional or third party websites are prohibited.

In most cases authors are permitted to post their version of the article (e.g. in Word or Tex form) to their personal website or institutional repository. Authors requiring further information regarding Elsevier's archiving and manuscript policies are encouraged to visit:

http://www.elsevier.com/copyright 


\title{
The Campanian Ignimbrite (Y5) tephra at Crvena Stijena Rockshelter, Montenegro
}

\author{
Mike W. Morley ${ }^{\mathrm{a}, *}$, Jamie C. Woodward ${ }^{\mathrm{b}, *}$ \\ ${ }^{a}$ Human Origins and Palaeo-Environments (HOPE) Group, Department of Anthropology and Geography, School of Social Sciences and Law, Oxford Brookes University, Gipsy Lane, \\ Oxford, OX3 OBP, UK \\ b Quaternary Environments and Geoarchaeology Research Group, Geography, School of Environment and Development, The University of Manchester, Oxford Road, Manchester, \\ M13 9PL, UK
}

\section{A R T I C L E I N F O}

\section{Article history:}

Received 4 June 2010

Available online 3 April 2011

\section{Key words:}

Distal tephra

Quaternary

Campanian Ignimbrite

Mediterranean

Rockshelter sediments

Middle to Upper Palaeolithic transition

Microstratigraphy

Sediment sources

\begin{abstract}
A B S T R A C T
Clearly defined distal tephras are rare in rockshelter sediment records. Crvena Stijena, a Palaeolithic site in Montenegro, contains one of the longest $(>20 \mathrm{~m}$ ) rockshelter sediment records in Europe with deposits ranging in age from Middle Pleistocene to mid-Holocene. A distinctive tephra is clearly exposed within the well stratified record approximately $6.5 \mathrm{~m}$ below the present land surface. We present geochemical data to confirm that this tephra is a distal equivalent of the Campanian Ignimbrite deposits and a product of the largest Late Pleistocene eruption in Europe. Originating in the Campanian volcanic province of southwest Italy, this tephra has been independently dated to $39.3 \mathrm{ka}$. It is a highly significant chronostratigraphic marker for southern Europe. Macrostratigraphic and microstratigraphic observations, allied with detailed particle size data, show that the tephra layer is in a primary depositional context and was transported into the rockshelter by aeolian processes. This site is unique because the tephra forms an abrupt boundary between the Middle and Upper Palaeolithic records. Before they can be used as chronostratigraphic markers in rockshelter and cave-mouth environments, it is essential to establish the stratigraphic integrity of distal tephras and the mechanisms and pathways involved in their transport and deposition.
\end{abstract}

(c) 2011 University of Washington. Published by Elsevier Inc. All rights reserved.

\section{Introduction}

Distal tephras can provide archaeologists and geoscientists with valuable chronostratigraphic markers (e.g. Vitaliano et al., 1981; Narcisi and Vezzoli, 1999; Pyle et al., 2006; Giaccio et al., 2008; Lane et al., 2011). These markers become especially important when they are found in relation to Palaeolithic material that lies close to or beyond the range of radiocarbon dating (Pawlikowski, 1992; Fumanal, 1997; Farrand, 2000; Fedele, 2002; Fedele et al., 2003; Pyle et al., 2006; Giaccio et al., 2006, 2008; Anikovich et al., 2007). Geological and archaeological records can be directly compared - even over large distances - should the same tephra layer be identified in-situ in both records. Research in the central and eastern Mediterranean region over many decades has produced one of the richest databases of Quaternary volcanic activity. Distal tephras now provide an important link between the marine and terrestrial records across this region (Narcisi and Vezzoli, 1999; Wulf et al., 2004) and high-resolution analysis has also highlighted the potential of microtephras in this area of research (Lowe et al., 2007). In this paper we report a significant new tephra exposure within a long archaeological record spanning the Middle to Upper Palaeolithic at Crvena Stijena rockshelter in Montenegro. Rockshelter and cave sediment records are important

\footnotetext{
* Corresponding authors.

E-mail addresses: mmorley@brookes.ac.uk (M.W. Morley), jamie.woodward@man.ac.uk (J.C. Woodward).
}

archives of environmental change and much of what we know about the Middle and Upper Palaeolithic records in southern Europe and the wider Mediterranean region has been recovered from these depositional environments (Woodward and Goldberg, 2001).

Chronological markers that are not reliant on radiocarbon assume particular importance when an archaeological sequence is thought to date to around $40 \mathrm{ka},-$ a period of intense interest to Quaternary scientists and archaeologists, as it broadly correlates with a number of important periods in climate history and human evolution including: i) the Middle to Upper Palaeolithic transition in Europe when anatomically modern humans spread across the continent and the Neanderthals disappeared from the fossil record (Mellars, 2004; Finlayson et al., 2006; Conard, 2006); ii) the global cooling of Heinrich Event 4 (HE4) (Paterne et al., 1999; Fedele et al., 2008); iii) the Laschamp Excursion ( $40.4 \pm 2 \mathrm{ka}$ ), which marks a profound reduction in the strength, and change in direction, of the geomagnetic field (Guillou et al., 2004; Lund et al., 2005); and marked increases in cosmogenic ${ }^{10} \mathrm{Be}$ and other nuclides such as ${ }^{14} \mathrm{C}$ and ${ }^{36} \mathrm{Cl}$ (e.g. Mazaud et al., 1991; Voelker et al., 2000).

Chronologies for this period based on radiocarbon are commonly associated with large errors and uncertainties (Pettitt et al., 2003; Blockley et al., 2008; Jöris and Street, 2008). The limited precision of this approach partly relates to elevated levels of atmospheric ${ }^{14} \mathrm{C}$ leading to younger dates, even with the use of the most recent calibration curves (Voelker et al., 2000; Beer et al., 2002; Pyle et al., 2006; Anikovich et al., 2007; Hoffecker et al., 2008). Thus radiocarbon 
chronologies have consistently underestimated the ages of wellconstrained tephra layers at several sites (e.g. Giaccio et al., 2006; Sinitsyn and Hoffecker, 2006). This is a major problem because much of our knowledge of the Middle to Upper Palaeolithic transition is founded on radiocarbon-based timescales and the calibration models for this period are still under development (Conard and Bolus, 2008; Jöris et al., 2003; Hughen et al., 2004).

Crvena Stijena is a key site for understanding the nature of the Middle to Upper Palaeolithic transition in the Balkans. It preserves an exceptionally deep ( $>20 \mathrm{~m}$ ) stratigraphy; one of the longest and most complete in Europe (Basler, 1975; Gamble, 1999; Baković et al., 2009). The Middle and Upper Palaeolithic periods account for most of the sedimentary record, but there is also evidence of site use during the Mesolithic and Neolithic (Table 1). The archaeological succession includes a long Mousterian sequence overlain by sediments containing lithic assemblages of Upper Palaeolithic tradition (Aurignacian and Gravettian) (Basler, 1975; Baković et al., 2009; Mihailović, 2009). A Neanderthal tooth was recovered from excavations at the site in 2004 (Baković et al., 2009). The site is also important because the eastern Adriatic coast is thought to have been an important route for the movement of anatomically modern humans from the Near East between ca. 50 and 30 ka (Kozlowski, 1998, 2006; Dennell, 2003; Roebroeks, 2008). It is likely that Neanderthals were still present in the region at this time, though the picture is extremely complex in terms of possible inter-species coexistence and issues surrounding technological transference (Kozlowski, 1998). Recent work on Pleistocene glacial records in this area has shed new light on the long-term palaeoenvironmental context for human settlement in this part of the Balkans. Large ice masses developed in the uplands of Montenegro during cold stages of the Pleistocene (Hughes and Woodward, 2009; Hughes et al., 2010). Well dated records show that glaciers extended down to $\mathrm{ca}$. $500 \mathrm{~m}$ above sea level in MIS 12 and ca. $1000 \mathrm{~m}$ above sea level in MIS 6. The presence of large glaciers and permanent snow cover across much of the upland landscape during cold stages would have presented a very challenging environmental setting for Palaeolithic humans at these times.

Archaeological investigations at Crvena Stijena in the 1960s and 1970s generated much information on the cultural, social and subsistence activities of Middle and Upper Palaeolithic hominins in the region (Basler, 1975). Following on from this first phase of research, preliminary observations and sampling of the sediment record were carried out by Jamie Woodward and Bob Whallon in 1998 and a renewed programme of multi-disciplinary investigation was initiated at the site in 2004 (Baković et al., 2009). This included a detailed programme of geoarchaeological research to provide envi-

\section{Table 1}

Major strata, archaeological periods and cultures at Crvena Stijena (modified from Basler, 1975). The archaeological periods follow Basler's (1975) scheme and the designations of geological context follow Brunnacker (1975)

\begin{tabular}{|c|c|c|c|}
\hline Stratum & Depth (m) & Archaeological context & $\begin{array}{l}\text { Geological } \\
\text { context }\end{array}$ \\
\hline I & $0-0.40$ & Bronze Age & Postglacial \\
\hline II-III & $0.40-1.80$ & Neolithic & \\
\hline IV & $1.80-2.90$ & Mesolithic & \\
\hline V-VII & $2.90-3.50$ & $\begin{array}{l}\text { Late Up per Palaeolithic } \\
\text { (Epipalaeolithic) }\end{array}$ & Würm \\
\hline VIII-IX & $3.50-4.90$ & Local UP based on Aurignacian & \\
\hline $\mathrm{X}$ & $4.90-7.60$ & Aurignacian & \\
\hline XI-XII & $7.60-8.30$ & Late Mousterian & \\
\hline XIII & $8.30-9.10$ & Denticulate Mousterian & \\
\hline XIV-XVII & $9.10-10.40$ & Mousterian & \\
\hline XVIII & $10.40-10.70$ & Pontinian & \\
\hline XIX-XX & $10.70-11.40$ & Mousterian with triangular points & \\
\hline XXI-XXII & $11.40-12.10$ & Pontinian & \\
\hline XXIII-XXIV & $12.10-15.40$ & Mousterian & Riss/Würm \\
\hline XXV-XXVIII & $15.40-17.80$ & Protomousterian & Riss \\
\hline XXIX-XXXI & $17.80-20.30$ & Premousterian & \\
\hline
\end{tabular}

ronmental context for the Middle to Upper Palaeolithic records (Morley, 2007). Against this background, this paper has the following aims:

1. To examine the stratigraphic and environmental context of the tephra unit at Crvena Stijena rockshelter to test the hypothesis that the tephra bed is in situ and has not been reworked;

2. To establish the provenance and age of the tephra unit and its wider chronostratigraphic significance.

3. In light of 1 and 2, to explore some of the key taphonomic issues associated with the transfer of distal tephra sediments into limestone caves and rockshelters and their incorporation into the sedimentary record.

\section{The Campanian Ignimbrite eruption}

The Campanian Ignimbrite tephra (also known as the Y5 tephra in the marine record) is a Late Pleistocene volcanic ash that originated from an eruption in the Phlegrean Fields region of the Campanian volcanic province in southwest Italy (Fig. 1, Thunell et al., 1979; Cramp et al., 1989; Rosi et al., 1999; Ton-That et al., 2001; Fedele et al., 2008; Sparks et al., 2005; Pyle et al., 2006; Blockley et al., 2008; Di Vito et al., 2008; Giaccio et al., 2008). This super-eruption (Sparks et al., 2005 ) is thought to have been the most powerful volcanic explosion in the Mediterranean region over the last $200 \mathrm{ka}$ (Barberi et al., 1978; Fedele et al., 2003, 2007, 2008; Oppenheimer and Pyle, 2009). It ejected around $300 \mathrm{~km}^{3}$ of volcanic material into the atmosphere, and its distal tephra has been found spread over an area of some 2 to $4 \times 10^{6} \mathrm{~km}^{2}$ (Sparks et al., 2005; Fedele et al., 2007, 2008; Giaccio et al., 2006, 2008; Oppenheimer and Pyle, 2009), including locations as far away as the Palaeolithic site cluster at Kostenki, Voronezh, on the River Don in southwest Russia (Pyle et al., 2006; Anikovich et al., 2007). It may even have reached North Africa (Barker et al., 2010).

The Campanian Ignimbrite tephra has been identified in a range of environmental archives including marine cores (Vinci, 1985; Cramp et al., 1989; Vezzoli, 1991; Ton-That et al., 2001), and terrestrial contexts, including lake sediments, peat bogs, open-air archaeological sites, and cave and rockshelter sequences (Fig. 1 and Table 2). This event has also been recognised in the Greenland ice-core records as a peak in sulphate ( $375 \mathrm{ppb}$ ) at $40.12 \mathrm{ka}_{\mathrm{GISP} 2}$ (Fedele et al., 2007). This is in good agreement with high-precision ${ }^{40} \mathrm{Ar} /{ }^{39} \mathrm{Ar}$ dating of the tephra which has yielded ages ranging from 39 to $41 \mathrm{ka}$ (Ton-That et al., 2001; De Vivo et al., 2001) and places the time of deposition within MIS 3 (ca.60-30 ka) (Van Andel and Davies, 2004; Hoffecker et al., 2008).

It has been argued that the immense volume of material ejected into the atmosphere, and its widespread dispersal, may have had a profound effect on climate at this time - perhaps even at the global scale. Fedele et al. (2008) have argued that the Campanian Ignimbrite event would have subjected the Mediterranean region to a "volcanic winter," and the coincidence with HE-4 (the coldest and driest of the Heinrich Events) could have resulted in what they term a "HE4-CI crisis." High sulphur levels associated with volcanic eruptions can lead to global cooling (Self, 2006), and some researchers claim that the Campanian Ignimbrite peak in sulphur, evident in the Greenland icecore record (Zielinski et al., 1996, 1997), may have precipitated the onset of a markedly cold climatic episode within the relatively warm, but climatically unstable, Interpleniglacial, or MIS 3 (Van Andel and Davies, 2004). It is not the purpose of this paper, however, to explore these issues and the wider environmental impacts of the Campanian Ignimbrite eruption. Instead we present new data on the tephra layer at Crvena Stijena and highlight the importance of establishing the precise stratigraphic and depositional context of such features in archaeological sites. This is a key first step before any analysis of the potential impacts of such an event on Late Pleistocene ecosystems and Palaeolithic societies can take place. 


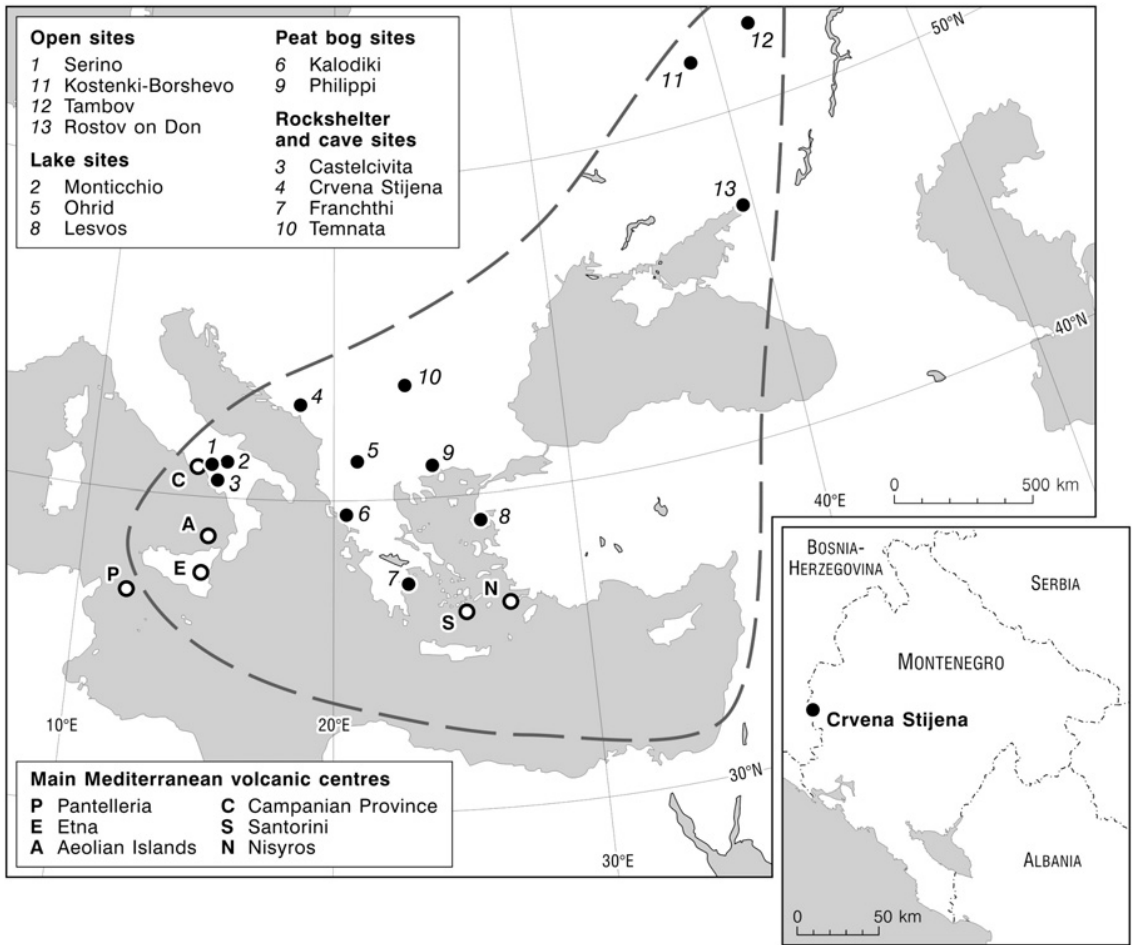

Figure 1. Map of the central and eastern Mediterranean and southeast Europe showing the major volcanic centres and key sites mentioned in the text that have been correlated with the Campanian Ignimbrite eruption. The dashed line shows the extent of the distal tephra (after Pyle et al., 2006). The inset map shows the location of Crvena Stijena rockshelter in western Montenegro.

\section{Crvena Stijena Rockshelter}

\section{Geomorphological setting and the tephra layer}

Crvena Stijena is a large SSW-facing rockshelter $\left(42.779^{\circ} \mathrm{N}\right.$, $18.481^{\circ} \mathrm{E}$ ) set in a prominent limestone cliff-face at $700 \mathrm{~m}$ above sea level in the western foothills of the Dinaric Alps, close to the border with Bosnia and Herzegovina, in southwest Montenegro (Figs. 1 and 2A; Basler, 1975; Morley, 2007; Baković et al., 2009). Locally, elevations rise to $1300 \mathrm{~m}$ in a steep, undulating topography of limestone hills. Today the landscape is partially covered by an open mosaic of low scrub and small localised areas of mixed woodland. The local limestone includes beds of dolomite and extensive folding, fracturing and jointing make these rocks particularly susceptible to mechanical breakdown. The rockshelter has a large opening $(26 \mathrm{~m}$ wide by $15 \mathrm{~m}$ high) with a horizontal depth of about $25 \mathrm{~m}$ (Fig. 2B).

The sedimentary sequence preserved at the site is exceptionally deep, with the thickest sediments at the rear of the site attaining a depth of over $20 \mathrm{~m}$ (Table1 and Fig. 3; Brunnacker, 1975). Systematic excavations were first carried out at the site in 1955 (Baković et al., 2009 for a review of the earlier work) and the main phase of work was lead by Duro Basler between 1960 and 1964 (Basler, 1975). This latter period involved the removal of huge volumes of sediment and the excavations reached over $20 \mathrm{~m}$ below the modern land surface. The stratigraphy was carefully recorded down to Layer XXXI (Table 1 and Fig. 3 ) but this is not the base of the sequence. The upper part of the site was later made safe with the construction of stepped stone wall terracing (Fig. 4). Using the Basler/Brunnacker scheme for recording the stratigraphy, the tephra layer at Crvena Stijena is Layer XI (Fig. 3). It lies some $6.5 \mathrm{~m}$ below the present day surface at the mouth of the rockshelter and is stratified between two beds of much coarser sediment (Layers X and XII) (Figs. 3 and 5). The tephra was first described by Brunnacker (1975) who argued for deposition within the hochglazial (high glacial). During the excavations in the 1960s, a radiocarbon date of $40,777 \pm 900{ }^{14} \mathrm{C}$ yr BP (GrN-6083; Basler, 1975: 90) was obtained from material taken from the stratigraphic unit immediately below the tephra (Figs. 3 and 5); although the exact position of the carbon sample within Layer XII is not known. This date has now been calibrated and is discussed further below. The latest excavations (2004-2008) have shown that the tephra forms a continuous and laterally extensive sheet extending across at least ca. $30 \mathrm{~m}^{2}$ of the site, with a variable thickness ranging from 5 to $10 \mathrm{~cm}$.

\section{Field and laboratory methods}

Well preserved exposures from earlier phases of excavations were utilised in this study and the stratigraphic units shown in Fig. 3 could be readily identified in many parts of the site. Following section cleaning, detailed recordings of the exposed sections were made in the form of sediment logs, drawings and photographs. Traditional bulk sediment sampling has been conducted in columns at a resolution of at least $5 \mathrm{~cm}$ throughout the full sequence (Morley, 2007 ) with most analyses focused on the fine sediment fraction $(<2 \mathrm{~mm}$ ) (Woodward and Goldberg, 2001). To study the record at higher resolution, samples of intact sediment blocks were also taken from various parts of the sequence using Kubiena tins for the preparation of thin sections for micromorphological analysis (e.g. Kourampas et al., 2009; Matarazzo et al., 2010). Samples of tephra were collected from the section shown in Fig. 5. These were subjected to a range of geochemical and physical analyses to allow comparison with the published tephra database from the Mediterranean region. Field and laboratory data have been integrated to establish the depositional context and sedimentation history of the tephra layer. The laboratory methods employed in this study are described in turn below.

\section{Micromorphology and particle size analysis}

A structurally intact block of sediment was removed from the exposed tephra section in a Kubiena tin and carefully packed for transport to the laboratory. After air-drying, the sediment block was impregnated with crystic polyester resin. The cured block 
Table 2

Terrestrial sites where a tephra layer has been correlated to the Campanian Ignimbrite tephra.

\begin{tabular}{|c|c|c|c|c|c|c|c|}
\hline Site & Location & $\begin{array}{l}\text { Distance } \\
\text { from source } \\
(\mathrm{km})\end{array}$ & Thickness & Archaeological context & $\begin{array}{l}\text { Method of } \\
\text { tephra } \\
\text { correlation }\end{array}$ & Dating control & References \\
\hline \multicolumn{8}{|c|}{ Open air sites } \\
\hline $\begin{array}{r}\text { Kostenki- } \\
\text { Borshevo }\end{array}$ & $\begin{array}{l}\text { Southwest } \\
\text { Russia }\end{array}$ & $2200 \mathrm{~km}$ & $\begin{array}{l}5-20 \mathrm{~cm} \\
(\text { locally }<1 \mathrm{~cm})\end{array}$ & $\begin{array}{l}\text { Around } 28 \text { separate sites of } \\
\text { Middle to Upper } \\
\text { Palaeolithic age }\end{array}$ & $\begin{array}{l}\text { EPMA; ICP-MS; } \\
\text { SEM; particle } \\
\text { size }\end{array}$ & $32,420 \pm 440{ }^{14} \mathrm{C}$ yr BP & $\begin{array}{l}\text { Pyle et al. 2006; Anikovich et al. } \\
\text { 2007; Hoffecker et al. } 2008\end{array}$ \\
\hline Serino & $\begin{array}{l}\text { Southern } \\
\text { Italy }\end{array}$ & $60 \mathrm{~km}$ & $275 \mathrm{~cm}$ & Proto-Aurignacian & Unknown & $\begin{array}{l}31,200 \pm 650{ }^{14} \mathrm{C} \text { yr BP (unit } \\
\text { below tephra) }\end{array}$ & $\begin{array}{l}\text { Accorsi et al. 1979; Fedele et al. } \\
\text { 2008; Giaccio et al. } 2008\end{array}$ \\
\hline \multicolumn{8}{|c|}{ Cave and rockshelters } \\
\hline Franchthi & $\begin{array}{l}\text { Peloponnese, } \\
\text { Greece }\end{array}$ & $800 \mathrm{~km}$ & $5-6 \mathrm{~cm}$ & $\begin{array}{l}\text { Below Upper Palaeolithic tool } \\
\text { assemblages }\end{array}$ & $\mathrm{XRF}$ & $33,000{ }^{14} \mathrm{C} \mathrm{BP}$ & $\begin{array}{l}\text { Vitaliano et al. 1981; } \\
\text { Farrand } 2000\end{array}$ \\
\hline $\begin{array}{l}\text { Crvena } \\
\text { Stijena }\end{array}$ & $\begin{array}{l}\text { Southwest } \\
\text { Montenegro }\end{array}$ & $450 \mathrm{~km}$ & $8-10 \mathrm{~cm}$ & $\begin{array}{l}\text { Middle Palaeolithic } \\
\text { (Mousterian) to Neolithic }\end{array}$ & $\begin{array}{l}\text { EPMA; SEM; } \\
\text { particle size }\end{array}$ & $\begin{array}{l}40,777 \pm 900{ }^{14} \mathrm{C} \text { yr BP } \\
\text { (unit below tephra) }\end{array}$ & $\begin{array}{l}\text { Basler 1975; Morley 2007; } \\
\text { Baković et al. } 2009\end{array}$ \\
\hline Temnata & Bulgaria & $850 \mathrm{~km}$ & $50-80 \mathrm{~cm}$ & $\begin{array}{l}\text { Middle Palaeolithic to } \\
\text { Epi-Gravettian }\end{array}$ & XRD, SEM & $\begin{array}{l}30,600 \pm 1,900 \text { to } 31,400 \pm \\
1,600{ }^{14} \mathrm{C} \text { yr BP (underling and } \\
\text { overlying layers) }\end{array}$ & $\begin{array}{l}\text { Kozlowski et al. 1992; } \\
\text { Pawlikowski 1992; Paterne } \\
1992\end{array}$ \\
\hline Castelcivita & Italy & $100 \mathrm{~km}$ & ca. $50 \mathrm{~cm}$ & $\begin{array}{l}\text { Mousterian to proto- } \\
\text { Aurignacian }\end{array}$ & EPMA & $\begin{array}{l}32,390 \pm 490{ }^{14} \mathrm{C} \text { yr BP } \\
\text { (unit below the tephra) }\end{array}$ & $\begin{array}{l}\text { Fumanal 1997; Giaccio et al. } \\
2006\end{array}$ \\
\hline \multicolumn{8}{|l|}{ Peat bogs } \\
\hline $\begin{array}{l}\text { Phillippi } \\
\text { marsh }\end{array}$ & Greece & $850 \mathrm{~km}$ & ca. $25 \mathrm{~cm}$ & NA & $\begin{array}{l}\text { EPMA, SEM, } \\
\text { XRD }\end{array}$ & $\begin{array}{l}28,134 \pm 716-31,577 \pm 570{ }^{14} \mathrm{C} \\
\text { yr BP (peat above and below) }\end{array}$ & St Seymour et al. 2004 \\
\hline $\begin{array}{l}\text { Kalodiki } \\
\text { Fen }\end{array}$ & Greece & $580 \mathrm{~km}$ & $10 \mathrm{~cm}$ & NA & $\begin{array}{l}\text { EPMA, SEM, } \\
\text { XRD }\end{array}$ & No & $\begin{array}{l}\text { St Seymour and Christanis } \\
1995\end{array}$ \\
\hline \multicolumn{8}{|l|}{ Lake basins } \\
\hline Mytilene & $\begin{array}{l}\text { Lesvos } \\
\text { Island, } \\
\text { Greece }\end{array}$ & $1050 \mathrm{~km}$ & & NA & $\begin{array}{l}\text { EPMA, ICP-MS, } \\
\text { particle size }\end{array}$ & $\begin{array}{l}{ }^{14} \mathrm{C} \text { AMS } 40,361 \pm 1,753{ }^{14} \mathrm{C} \text { yr } \\
\text { BP }\end{array}$ & Margari et al. 2007 \\
\hline Monticchio & Italy & $125 \mathrm{~km}$ & & NA & $\begin{array}{l}\text { Sedimentology; } \\
\text { EPMA }\end{array}$ & 32,970 varve $\mathrm{yr}$ & $\begin{array}{l}\text { Narcisi 1996; Allen et al. 1999, } \\
\text { 2000; Wulf et al. } 2004\end{array}$ \\
\hline Ohrid & $\begin{array}{l}\text { Macedonia/ } \\
\text { Albania }\end{array}$ & $550 \mathrm{~km}$ & & NA & & & Wagner et al. 2008 \\
\hline
\end{tabular}

$(80 \times 60 \mathrm{~mm})$ was sawn in half, polished and then glued to an $85 \times 65 \times 3 \mathrm{~mm}$ glass slide. This block was then sawn again to leave approximately $1 \mathrm{~mm}$ of impregnated sediment which was ground down to a thickness of $30 \mu \mathrm{m}$. The thin section was examined using a standard polarising microscope at magnifications ranging from $\times 10$ to $\times 400$ in both PPL and XPL. Descriptions and interpretations of features observed in the thin section were carried out in accordance with criteria set out in Stoops (2003) following Bullock et al. (1985). To determine the grain size characteristics of the tephra and to ascertain whether there were any vertical variations in particle size, four samples were collected in $20 \mathrm{~mm}$ vertical increments through an $80 \mathrm{~mm}$-thick exposure in Layer XI. The samples were dispersed and then analysed using a Beckman Coulter LS 230 laser diffraction particle size analyser.

Scanning electron microscopy and electron probe micro-analysis (EPMA)

A JEOL JSM-820 SEM was used at an accelerating voltage of $5 \mathrm{kV}$ to capture images of tephra shards and pumice grains. These images were compared to the morphological properties of glass pyroclasts observed in other tephra layers found in the Mediterranean region (e.g. Vezzoli, 1991; Narcisi and Vezzoli, 1999). Major element geochemical data were generated using a fully automated JEOL 8900 electron microprobe using a wavelength-dispersive spectrometer (WDS) with an accelerating voltage of $15 \mathrm{kV}$, a beam current of $10 \mathrm{nA}$, and a defocused beam diameter of $10 \mu \mathrm{m}$. Analyses were undertaken on polished thin sections made from resin-embedded tephra pyroclasts. We analysed the composition of 41 glass shards after omitting analyses with a sum of total oxides $<95 \mathrm{wt} \%$. All analyses were recalculated to $100 \mathrm{wt} . \%$.

\section{Results}

\section{Geochemistry}

Figure 6 shows that the tephra has a geochemical signature consistent with the Campanian volcanic province of southwest Italy, which comprises Vesuvius, the Phlegrean Fields and the islands of Ischia and Procida-Vivara (Wulf et al., 2004). The electron microprobe dataset for Layer XI at Crvena Stijena is shown in Table 3. Quaternary volcanic events in the Campanian province have been well documented (Narcisi and Vezzoli, 1999). Here we use the alpha-numeric nomenclature of Keller et al. (1978) - recently expanded by Calanchi and Dinelli (2008) - that was developed for marine occurrences of the Campanian Ignimbrite. There are several known Late Pleistocene tephras with Campanian origins (Table 4). We rule out the ' $X$ ' series tephras owing to the greater age of these volcanic events ( $c a .110$ to $70 \mathrm{ka}$; Narcisi and Vezzoli 1999) in comparison to the archaeological assemblages immediately above and below Layer XI at Crvena Stijena. The Y7 tephra has been identified in marine cores (Keller et al., 1978), and in sediments from the Monticchio lake basin (Allen et al. 1999; Wulf et al. 2004). The estimated ${ }^{40} \mathrm{Ar} /{ }^{39} \mathrm{Ar}$ age of $56 \pm 4 \mathrm{ka}$ (Kraml 1997; Allen et al. 1999) is too early for the Middle to Upper Palaeolithic transition. The Y3 tephra has been identified across the Mediterranean basin in terrestrial, marine and lacustrine environments (Zanchetta et al. 2008). At around $30-31 \mathrm{ka}$, it could be a plausible candidate for the Crvena Stijena ash. However, the chemical composition of the Y3 tephra is readily distinguishable from other Campanian tephras of similar age (Munno and Petrosino, 2004; Zanchetta et al., 2008) and can therefore be ruled out.

Another tephra to be noted at this point is the little known Codola tephra. This tephra has been recognised in the Monticchio lacustrine sequence (e.g. Wulf et al., 2004), as well as in sediments 
a

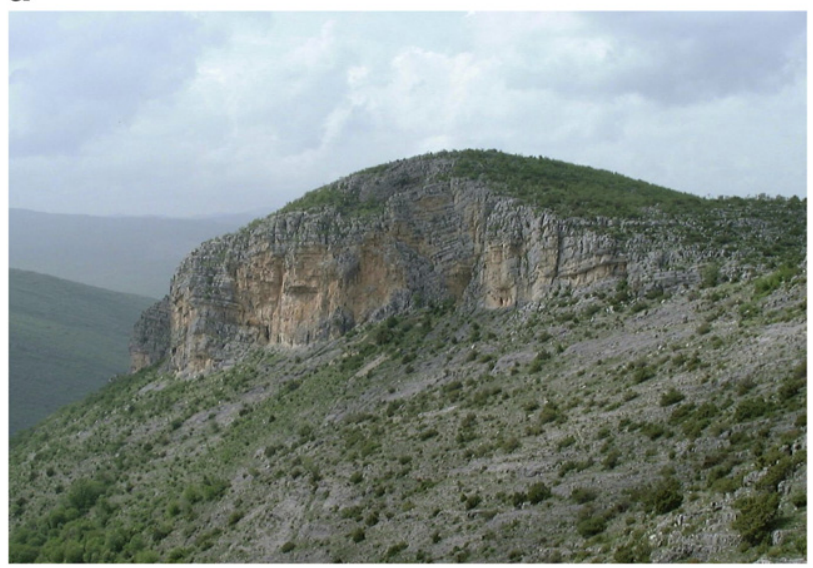

b

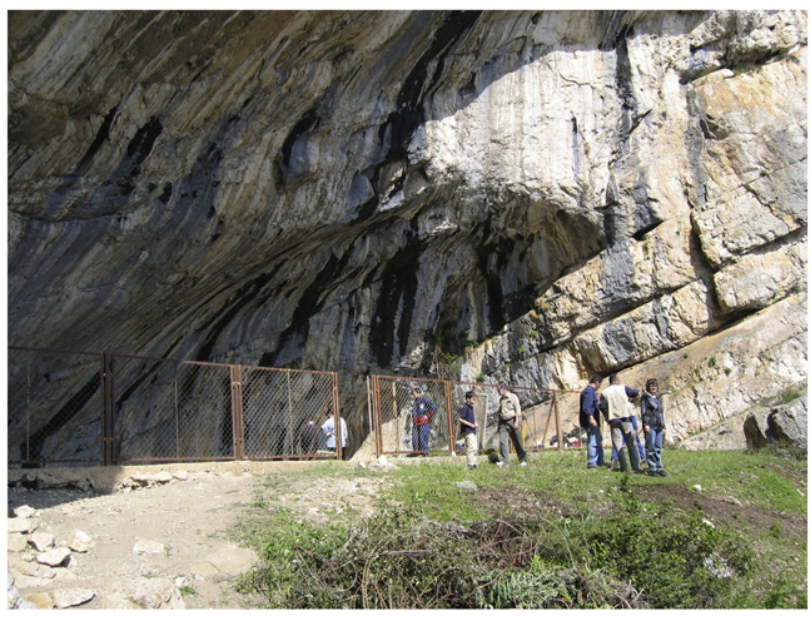

Figure 2. A) The local setting of Crvena Stijena rockshelter. The site is located on the right side of the main cliff face. B) The rockshelter opening in summer 2005.

of the inter-montane lake of San Gregorio Magno in the Southern Apennines (Munno and Petrosino, 2007). Stratigraphically, this chemically and physically heterogeneous tephra (Santacroce et al., 2008), lies between the Campanian Ignimbrite (Y5) and the Y3 tephra and is dated to around $33 \mathrm{ka}$ (Giaccio et al., 2008). Given its young age relative to the Middle to Upper Palaeolithic boundary, the geochemical and physical contrasts with the Campanian Ignimbrite, and its comparatively limited known areal extent, the Codola tephra is a highly unlikely candidate for the tephra of Layer XI at Crvena Stijena.

The geochemical data indicate a correlation between the Crvena Stijena ash and the Campanian Ignimbrite volcanic event, dated to $39.3 \mathrm{ka}$ (De Vivo et al., 2001; Ton-That et al., 2001; Oppenheimer and Pyle, 2009). This age is supported by the radiocarbon date of $40,777 \pm 900{ }^{14} \mathrm{C}$ yr BP (GrN-6083; Basler, 1975: 90) obtained from charcoal in layer XII immediately below the tephra (Figs. 4 and 5), although the precise depth of this charcoal sample within Layer XII is not known. If this radiocarbon assay is reliable, when calibrated using CalPal 2007 HULU, it gives an age of $44,337 \pm 973$ cal yr BP and, notwithstanding some of the problems associated with the calibration of radiocarbon ages around this time, this places at least part of Layer XII a few thousand years before the eruption.

Further support for this correlation is provided by Fig. 7 which shows the close chemical composition of the Crvena Stijena ash to other published geochemical data for distal tephra that have been correlated with the Campanian Ignimbrite eruption around $39.3 \mathrm{ka}$. This totalalkali-silica (TAS) diagram (after Le Bas et al., 1986) presents the Crvena
Stijena results alongside published data for the Campanian Ignimbrite tephra and several other eruptions. The Crvena Stijena data exhibit significant trachytic-phonolitic variability, with $\mathrm{ca}$. $75 \%$ of the samples possessing a phonolitic composition. Such geochemical variability is a highly diagnostic characteristic of the Campanian Ignimbrite tephra (Vezzoli, 1991; Civetta et al., 1997; Ton-That et al., 2001; Pyle et al., 2006; Giaccio et al., 2008) and its significance will be discussed further below.

\section{Shard morphology}

There is a close match between the morphology of the tephra shards in Layer XI and the known characteristics of the Campanian Ignimbrite (Y5) tephra. The key morphological characteristics of the Crvena Stijena ash, which display very close affinities to the Campanian Ignimbrite tephra, are ' $Y$ '-shaped, flat or curved shards created by the fragmentation of large vesicle walls; elongate shards with pipe wall vesicles; preserved intact spherical vesicles; and highly vesicular pumice grains (Pyle et al., 2006). Some examples from Layer $\mathrm{XI}$ are shown in Fig. 8.

\section{Microstratigraphy}

Clearly defined tephra layers with distinct upper and lower bounding surfaces are rare in cave and rockshelter settings. The thickness of the Crvena Stijena tephra $(\leq 10 \mathrm{~cm})$, and the excellent exposure (Fig. 5), allowed us to take intact samples of the tephra for the first time in such a setting to examine its microstratigraphy in order to determine its taphonomic history. Observations in thin section show that the tephra is a densely packed and homogeneous mass of glass shards and pumice grains, with occasional $(<1 \%)$ fine sand-sized mineral grains (Fig. 9). Importantly, there is no evidence for waterborne deposition; microlaminae or vertical grading, which could indicate remobilisation by fluvial or colluvial processes, are absent (Woodward et al., 2001). If such reworking had taken place it might be expected that the elongate shards - a typical feature of the Campanian Ignimbrite distal tephra - would become aligned with respect to the direction of flow.

\section{Particle size analysis}

Particle size distributions for four samples taken through the tephra at Crvena Stijena are presented in Fig. 10. These show that the lowermost sub-sample $(0-20 \mathrm{~mm})$ is the coarsest, with overlying samples $(20-40,40-60$ and $60-80 \mathrm{~mm})$ showing a clear fining upwards trend. Together with the microstratigraphic observations, the particle size data indicate that the tephra was deposited as a single unit by aeolian processes and has not been subjected to significant post-depositional reworking.

The particle size distribution of the ash shows an essentially unimodal distribution ( $c a .125-250 \mu \mathrm{m}$ ), with a subtle "step" in the curve at 16-31 $\mu \mathrm{m}$ and these characteristics agree well with the work of Pyle (1989) and Pyle et al. (2006). At $\geq 1500 \mathrm{~km}$ from source the coarse (fine sand, $125-250 \mu \mathrm{m}$ ) component is removed during transit, and coarse silt $(16-31 \mu \mathrm{m})$ dominates the distribution. This is the situation at Kostenki in southwest Russia where the tephra is unimodal at ca. 31-88 $\mu \mathrm{m}$ (very coarse silt to very fine sand) (Pyle et al., 2006). Closer to source, Pyle (1989) highlights the importance of the coarse mode which, having yet to be removed during transit, results in a bi-modal particle size distribution. At only $500 \mathrm{~km}$ from source, the grain size distribution of the Crvena Stijena tephra is rather different, with up to $35 \%$ of the sample having a coarse mode at 125-250 $\mu \mathrm{m}$ and a much less pronounced mode at 16-31 $\mu \mathrm{m}$ (Fig. 10).

Figure 11 shows the relationship between distance from source and grain size distribution for samples of the CI tephra. As Pyle (1989) asserts, the fine mode stays relatively stable with distance from the 


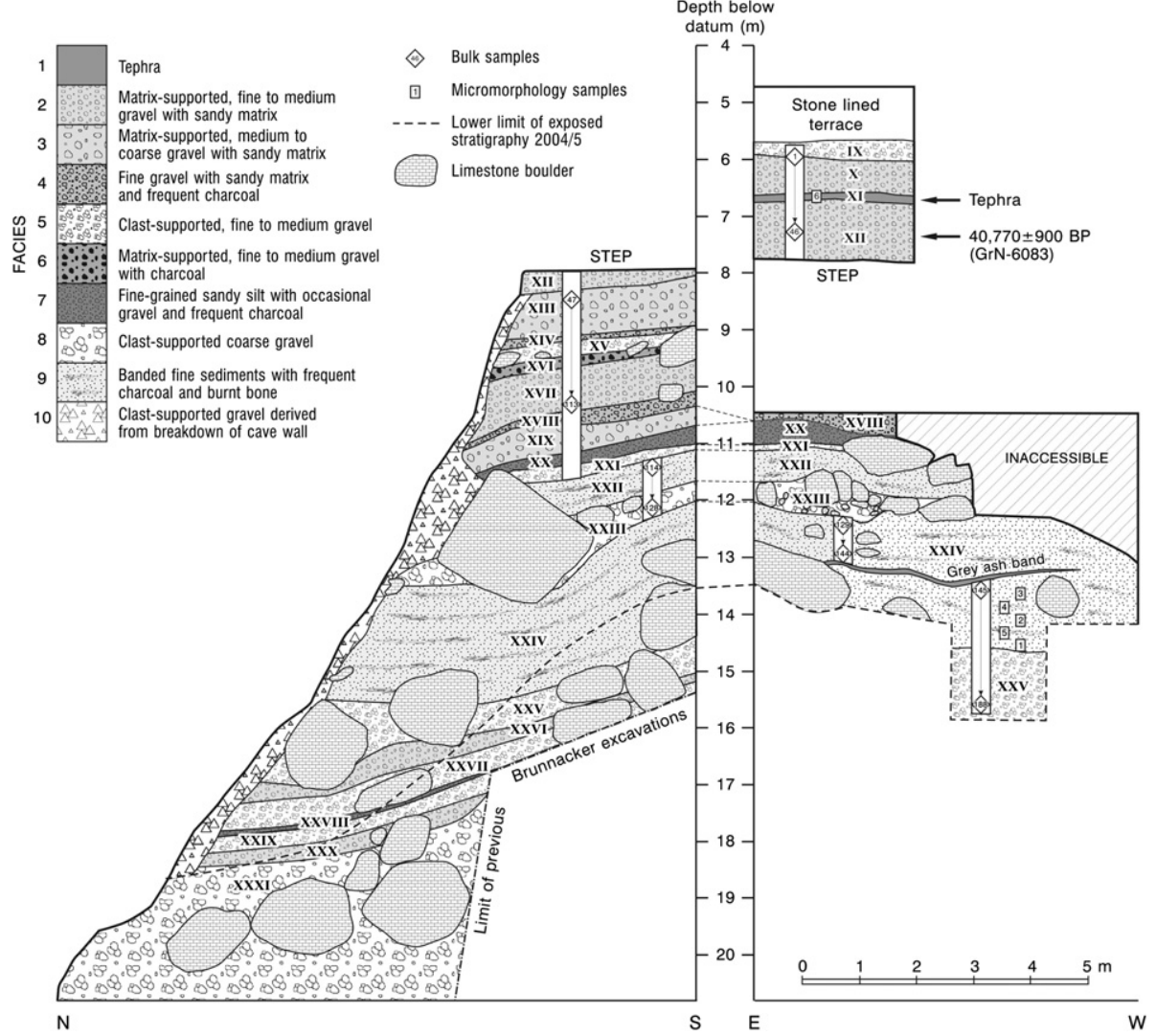

Figure 3. Composite section through the Middle Palaeolithic sequence, with the tephra layer (XI) and base of the Upper Palaeolithic (X and IX) seen at the top of the profile (based on Brunnacker 1975). The radiocarbon date is uncalibrated $\left({ }^{14} \mathrm{C}\right.$ yr BP).

eruption but with a gradual reduction in the coarse fraction. Crvena Stijena rockshelter is located approximately $500 \mathrm{~km}$ away from the Campanian region of southwest Italy and our data agree well with those published by Pyle (1989), with the fine mode and the coarse mode both lying on their respective trend lines.

\section{Discussion}

Correlation of the Crvena Stijena ash with the Campanian Ignimbrite tephra

Our multi-proxy approach shows a clear equivalence between the Layer XI ash and the distal tephra of the Campanian Ignimbrite. Indeed, Crvena Stijena lies within the most recent distribution map showing the dispersal of the tephra (Fig. 1) compiled by Pyle et al. (2006). The geochemical data indicate a Campanian origin and show very close affinities with material originating from the Phlegrean Fields area of the Campanian volcanic province. This correlation is also supported by the morphological characteristics of the glass pyroclasts. The distinctive physical attributes of the Campanian Ignimbrite tephra are observed throughout the Crvena Stijena ash. The particle size curves from Layer XI shown in Fig. 10 agree well with published particle size data for the Campanian Ignimbrite tephra (Pyle, 1989; Pyle et al., 2006). This correlation also receives support from our calibration of the original radiocarbon date $(\mathrm{GrN}-6083)$ that was obtained during the earlier excavations (Basler, 1975: 90).

The significance of the Campanian Ignimbrite tephra at Crvena Stijena

The published literature shows that macroscale distal tephra layers with clearly defined upper and lower contacts are rare in cave and rockshelter settings. To the authors' knowledge, only three other confirmed occurrences of the Campanian Ignimbrite tephra have been reported from cave and rockshelter contexts. In order of distance from source (proximal to distal) these are Castelcivita Cave, Italy (Fumanal, 1997; Giaccio et al., 2006); Franchthi Cave, Peloponnese, Greece (Vitaliano et al., 1981; Farrand, 2000); and Temnata Cave, Bulgaria (Kozlowski et al., 1992; Pawlikowski, 1992). All of these sites are shown in Fig. 1. The proximity of Castelcivita Cave to the Phlegrean Fields precludes the study of the distal characteristics of the ash at that site. To date, only rather limited analyses have been carried out on the tephra from Franchthi (Vitaliano et al., 1981) and Temnata (Pawlikowski, 1992). Paglicci Cave in Apulia, Italy (Palma di Cesnola,

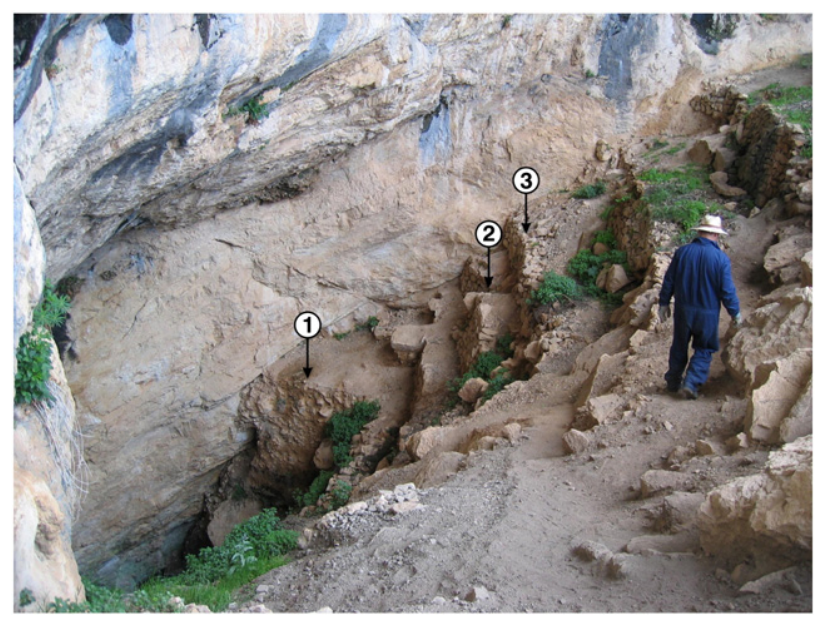

Figure 4. The interior of Crvena Stijena rockshelter in 2005. The original excavations removed a huge volume of material and the sections had to be stabilised with stone facing The numbers show: 1) the step in Fig. 3; 2) the location where the tephra was sampled and 3) the upper part of Layer X. Later excavations (2006-2008) exposed the surface of the tephra over an area of $c .30 \mathrm{~m}^{2}$ angled steeply back from the mouth of the site. 

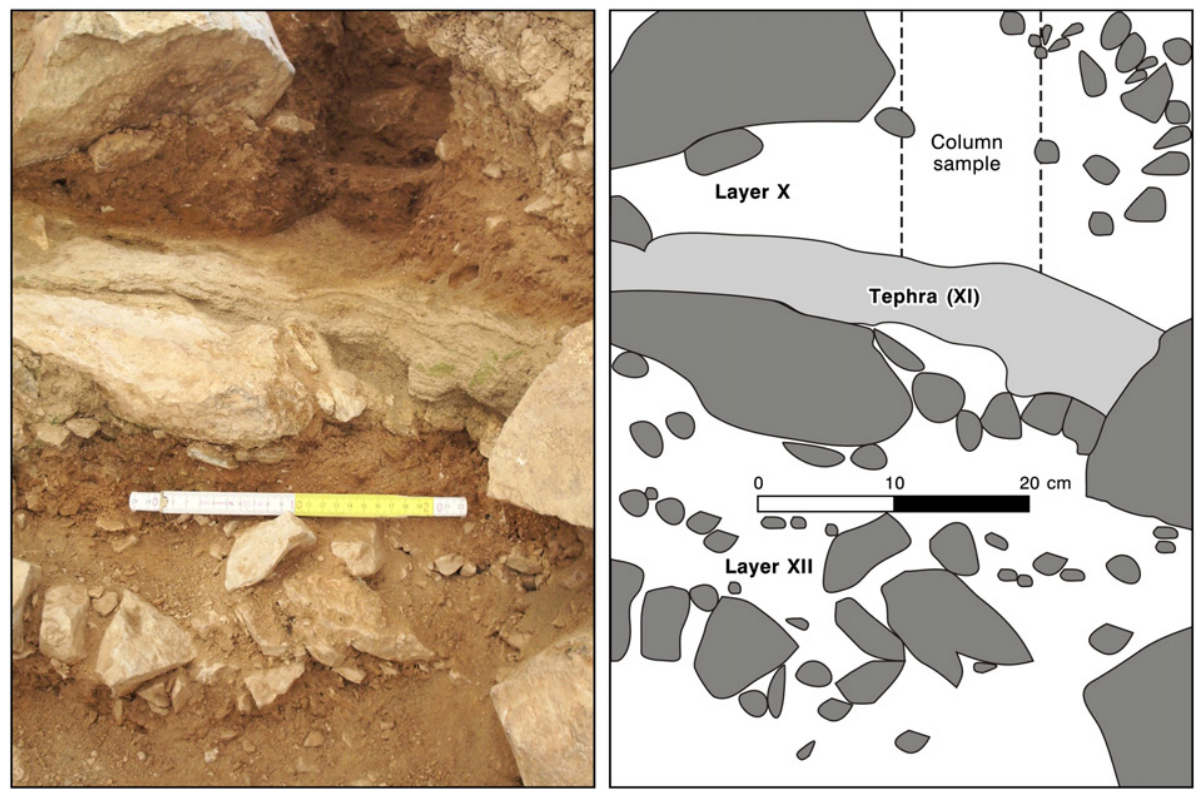

Figure 5. The tephra layer (XI) exposed at Crvena Stijena in June 2005. Note the disposition of the lower part of the tephra layer draped across the surface of the boulders indicating that it was blown into the site.

2006) has a tephra layer which was thought to relate to the Campanian Ignimbrite in terms of the associated archaeological material (Fedele et al., 2003). However, recent work by Giaccio et al. (2008) has confirmed that this tephra is in fact the much less studied Codola tephra which has been dated to $\mathrm{ca}$. 33 cal ka BP (Giaccio et al., 2008: 215)-it is therefore much younger than the Campanian Ignimbrite.

The large opening and SSW aspect of the rockshelter mouth, allied to its prominent elevated position (Fig. 2), make Crvena Stijena an ideal candidate for trapping windblown material from the southwest. Most rockshelters are not in such favourable locations. Unfavourable aspects and/or enclosed topographic settings have hindered the transfer of windblown tephra particles into the shelter opening. In caves and rockshelters where distal tephra particles have entered sites in low quantities, prominent layers of volcanic ash have not been able to form and the tephra material will become dispersed within a sediment matrix of more local origin. The tephra at Crvena Stijena was recognised as a volcanic ash over 30 years ago by Brunnacker (1975): 186-187. Since that time a correlation with the Campanian Ignimbrite tephra has been mooted, primarily because of its position at the boundary between the Middle and Upper Palaeolithic lithic assemblages, but also through other lines of evidence such as mineralogical composition (e.g. Pawlikowski, 1992). At Temnata Cave in Bulgaria, Pawlikowski has reported "similarities in stratigraphic and in refraction indexes" (Pawlikowski, 1992: 96) between the Temnata ash and the tephra at Crvena Stijena, as reported by Brunnacker (1975). Pawlikowski goes on to state that though Brunnacker did not present glass geochemical data, the "mineralogical composition of tephras from Crvena Stijena and Temnata Caves seems to be very similar" (1992: 96). Our data confirm that the tephra bed at Crvena Stijena is the distal equivalent of the Campanian Ignimbrite eruption.

The presence of the Campanian Ignimbrite tephra at Crvena Stijena is highly significant. The site is currently under renewed archaeological and geoarchaeological investigation, and given the long archaeological sequence, the identification of this key marker horizon will be important in the interpretation of any new archaeological and palaeoenvironmental data from the site. The importance of the $\mathrm{CI}$ tephra as an independent chronological marker also has far-reaching implications for our understanding of issues surrounding the Middle to Upper Palaeolithic transition and the potential co-existence of Neanderthals and Anatomically Modern Humans (e.g. Karavanic and
Smith, 2000). The identification of the Campanian Ignimbrite tephra within this archaeological sequence will ensure that the dating of this transition is not hampered by the uncertainties associated with radiocarbon-dated sequences of the same age (Pyle et al., 2006). Additionally, the sedimentary sequence has recently been the subject of a high-resolution palaeoenvironmental reconstruction by the authors which will be presented in detail elsewhere. This will provide important environmental context for the archaeological record.

Fedele et al. (2008) have argued that "the $\mathrm{CI}$ marks a behavioural watershed over a sizeable area between peninsular Italy and the eastern Balkans" (2008: 845), and that long Middle to Upper Palaeolithic sequences from sites in this area often contain evidence

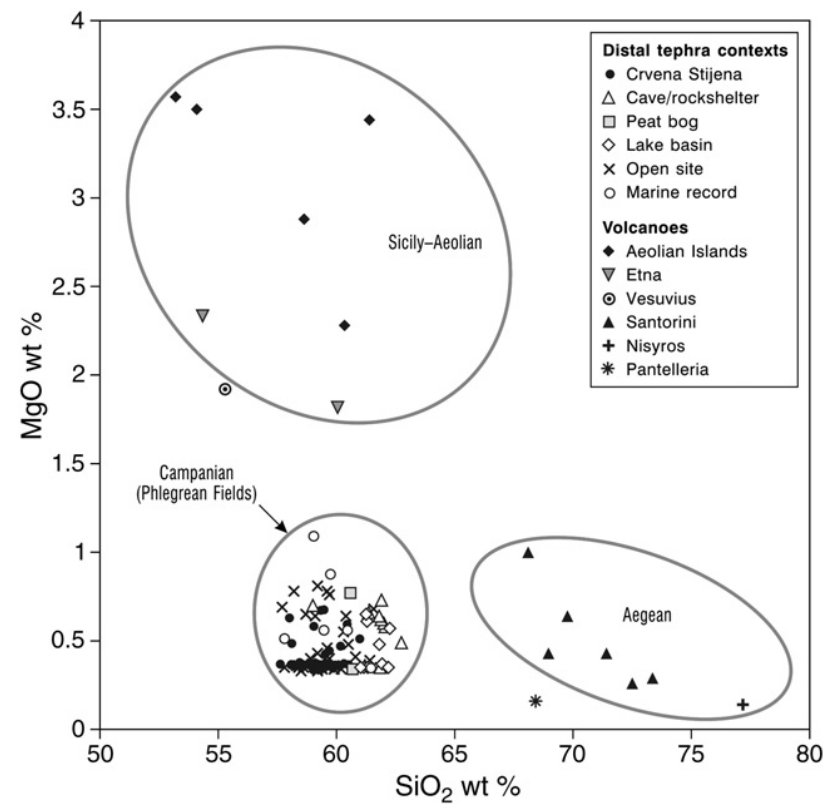

Figure 6. Plot of $\mathrm{SiO}_{2}$ against $\mathrm{MgO}$ showing data from the Crvena Stijena (Layer XI) tephra and other published data for the Campanian Ignimbrite tephra (from various marine and terrestrial sites cited in the text) alongside data from eruptions occurring in the other major Mediterranean Quaternary volcanic centres. The Crvena Stijena ash has close affinities with tephra known to have originated in the Campanian volcanic province (Phlegrean Fields) of southwest Italy. 
Table 3

Electron microprobe data (wt\%) for Layer XI at Crvena Stijena.

\begin{tabular}{|c|c|c|c|c|c|c|c|c|c|c|c|}
\hline & $\# 1$ & $\# 2$ & \#3 & $\# 4$ & \#5 & \#6 & \#7 & $\# 8$ & \#9 & $\# 10$ & \#11 \\
\hline $\mathrm{SiO}_{2}$ & 58.18 & 59.54 & 59.04 & 58.15 & 59.36 & 60.45 & 59.05 & 59.61 & 59.56 & 59.83 & 59.02 \\
\hline $\mathrm{TiO}_{2}$ & 0.45 & 0.45 & 0.37 & 0.43 & 0.45 & 0.37 & 0.43 & 0.45 & 0.44 & 0.44 & 0.43 \\
\hline $\mathrm{Al}_{2} \mathrm{O}_{3}$ & 18.84 & 19.17 & 18.4 & 18.68 & 19.06 & 18.54 & 18.9 & 18.78 & 19 & 19.01 & 18.68 \\
\hline $\mathrm{FeO}$ & 3.1 & 2.88 & 2.89 & 2.93 & 3.02 & 3.01 & 3.03 & 2.89 & 3.06 & 3.01 & 2.79 \\
\hline $\mathrm{MnO}$ & 0.23 & 0.24 & 0.11 & 0.22 & 0.23 & 0.12 & 0.23 & 0.23 & 0.23 & 0.23 & 0.22 \\
\hline $\mathrm{MgO}$ & 0.36 & 0.37 & 0.58 & 0.36 & 0.36 & 0.59 & 0.35 & 0.37 & 0.37 & 0.36 & 0.34 \\
\hline $\mathrm{CaO}$ & 1.77 & 1.83 & 2.16 & 1.74 & 1.78 & 2.2 & 1.68 & 1.76 & 1.82 & 1.82 & 1.65 \\
\hline $\mathrm{Na}_{2} \mathrm{O}$ & 6.38 & 5.99 & 5.15 & 5.22 & 6.4 & 5.44 & 6.17 & 6.44 & 6.24 & 6.44 & 5.84 \\
\hline $\mathrm{K}_{2} \mathrm{O}$ & 7.17 & 7.05 & 7.37 & 7.77 & 7.09 & 7.14 & 6.95 & 7.17 & 7.67 & 7.41 & 7.41 \\
\hline Total & 96.48 & 97.52 & 96.07 & 95.49 & 97.75 & 97.86 & 96.8 & 97.69 & 98.39 & 98.55 & 96.37 \\
\hline \multirow[t]{2}{*}{ Total alkali } & 13.55 & 13.04 & 12.52 & 12.99 & 13.49 & 12.58 & 13.12 & 13.61 & 13.91 & 13.85 & 13.25 \\
\hline & $\# 12$ & $\# 13$ & \#14 & \#15 & \#16 & $\# 17$ & $\# 18$ & \#19 & \#20 & $\# 21$ & $\# 22$ \\
\hline $\mathrm{SiO}_{2}$ & 58.50 & 59.34 & 60.14 & 59.52 & 59.59 & 60.31 & 59.11 & 59.54 & 60.98 & 60.17 & 59.60 \\
\hline $\mathrm{TiO}_{2}$ & 0.44 & 0.36 & 0.44 & 0.40 & 0.44 & 0.44 & 0.45 & 0.45 & 0.37 & 0.37 & 0.44 \\
\hline $\mathrm{Al}_{2} \mathrm{O}_{3}$ & 18.93 & 17.88 & 18.65 & 18.50 & 19.07 & 18.91 & 19.25 & 18.9 & 18.29 & 18.09 & 18.56 \\
\hline $\mathrm{FeO}$ & 2.94 & 3.40 & 3.10 & 2.87 & 3.03 & 2.99 & 2.99 & 2.92 & 2.78 & 2.81 & 3.00 \\
\hline $\mathrm{MnO}$ & 0.23 & 0.11 & 0.23 & 0.16 & 0.24 & 0.23 & 0.23 & 0.24 & 0.14 & 0.14 & 0.23 \\
\hline $\mathrm{MgO}$ & 0.36 & 0.67 & 0.36 & 0.42 & 0.37 & 0.37 & 0.38 & 0.37 & 0.51 & 0.47 & 0.37 \\
\hline $\mathrm{CaO}$ & 1.80 & 2.38 & 1.79 & 1.84 & 1.79 & 1.91 & 1.80 & 1.81 & 2.09 & 1.91 & 1.74 \\
\hline $\mathrm{Na}_{2} \mathrm{O}$ & 6.25 & 3.75 & 6.29 & 5.41 & 6.57 & 6.11 & 6.40 & 6.35 & 4.73 & 5.02 & 6.19 \\
\hline $\mathrm{K}_{2} \mathrm{O}$ & 7.32 & 9.37 & 7.75 & 7.30 & 7.11 & 7.58 & 7.05 & 6.97 & 8.61 & 8.20 & 7.03 \\
\hline Total & 96.76 & 97.25 & 98.74 & 96.43 & 98.19 & 98.86 & 97.65 & 97.55 & 98.49 & 97.18 & 97.16 \\
\hline \multirow[t]{2}{*}{ Total alkali } & 13.57 & 13.12 & 14.04 & 12.71 & 13.68 & 13.69 & 13.45 & 13.32 & 13.34 & 13.22 & 13.22 \\
\hline & \#23 & $\# 24$ & \#25 & \#26 & \#27 & $\# 28$ & $\# 29$ & \#30 & \#31 & \#32 & \#33 \\
\hline$\overline{\mathrm{SiO}_{2}}$ & 59.95 & 60.05 & 59.27 & 58.89 & 60.51 & 58.93 & 58.09 & 58.08 & 57.63 & 58.11 & $\overline{60.06}$ \\
\hline $\mathrm{TiO}_{2}$ & 0.44 & 0.45 & 0.43 & 0.43 & 0.45 & 0.43 & 0.44 & 0.43 & 0.43 & 0.40 & 0.43 \\
\hline $\mathrm{Al}_{2} \mathrm{O}_{3}$ & 18.65 & 18.85 & 18.58 & 18.71 & 18.85 & 18.98 & 19.04 & 18.91 & 18.80 & 18.45 & 18.88 \\
\hline $\mathrm{FeO}$ & 2.99 & 2.85 & 3.09 & 3.02 & 3.05 & 2.97 & 3.01 & 2.94 & 2.97 & 3.07 & 3.11 \\
\hline $\mathrm{MnO}$ & 0.23 & 0.24 & 0.22 & 0.23 & 0.25 & 0.24 & 0.24 & 0.23 & 0.23 & 0.17 & 0.25 \\
\hline $\mathrm{MgO}$ & 0.36 & 0.36 & 0.37 & 0.37 & 0.37 & 0.36 & 0.37 & 0.36 & 0.37 & 0.49 & 0.36 \\
\hline $\mathrm{CaO}$ & 1.74 & 1.76 & 1.72 & 1.80 & 1.76 & 1.73 & 1.72 & 1.72 & 1.83 & 2.02 & 1.76 \\
\hline $\mathrm{Na}_{2} \mathrm{O}$ & 6.52 & 6.46 & 6.48 & 6.34 & 6.52 & 6.51 & 6.47 & 6.33 & 6.33 & 5.70 & 6.30 \\
\hline $\mathrm{K}_{2} \mathrm{O}$ & 7.03 & 6.98 & 7.27 & 7.26 & 7.10 & 7.02 & 6.90 & 7.09 & 7.14 & 7.42 & 7.05 \\
\hline Total & 97.92 & 98.00 & 97.44 & 97.05 & 98.85 & 97.17 & 96.29 & 96.09 & 95.73 & 95.84 & 98.19 \\
\hline \multirow[t]{2}{*}{ Total alkali } & 13.55 & 13.44 & 13.75 & 13.6 & 13.62 & 13.53 & 13.37 & 13.42 & 13.47 & 13.12 & 13.35 \\
\hline & \#34 & \#35 & \#36 & \#37 & \#38 & \#39 & $\# 40$ & \#41 & & & \\
\hline $\mathrm{SiO}_{2}$ & 59.7 & 58.01 & 58.47 & 59.56 & 58.31 & 59.99 & 59.47 & 58.44 & & & \\
\hline $\mathrm{TiO}_{2}$ & 0.38 & 0.36 & 0.43 & 0.43 & 0.43 & 0.43 & 0.36 & 0.43 & & & \\
\hline $\mathrm{Al}_{2} \mathrm{O}_{3}$ & 18.50 & 18.05 & 18.52 & 18.8 & 18.84 & 18.91 & 17.98 & 18.75 & & & \\
\hline $\mathrm{FeO}$ & 2.90 & 3.04 & 3.01 & 2.98 & 3.00 & 3.09 & 3.21 & 3.05 & & & \\
\hline $\mathrm{MnO}$ & 0.16 & 0.11 & 0.23 & 0.23 & 0.23 & 0.24 & 0.10 & 0.23 & & & \\
\hline $\mathrm{MgO}$ & 0.44 & 0.63 & 0.36 & 0.36 & 0.36 & 0.36 & 0.68 & 0.38 & & & \\
\hline $\mathrm{CaO}$ & 1.86 & 2.31 & 1.73 & 1.70 & 1.78 & 1.78 & 2.37 & 1.79 & & & \\
\hline $\mathrm{Na}_{2} \mathrm{O}$ & 5.59 & 3.83 & 6.41 & 6.22 & 6.39 & 6.55 & 3.48 & 6.24 & & & \\
\hline $\mathrm{K}_{2} \mathrm{O}$ & 7.26 & 9.15 & 6.99 & 7.41 & 6.93 & 7.00 & 9.65 & 7.35 & & & \\
\hline Total & 96.8 & 95.48 & 96.14 & 97.69 & 96.26 & 98.35 & 97.28 & 96.65 & & & \\
\hline Total alkali & 12.85 & 12.98 & 13.40 & 13.63 & 13.32 & 13.55 & 13.13 & 13.59 & & & \\
\hline
\end{tabular}

suggestive of site abandonment following the eruption. Fedele et al. (2002) claim that a number of sites on mainland Italy witness a significant hiatus in occupation following the deposition of tephra that is likely to correlate with the Campanian Ignimbrite (based largely on stratigraphic position within archaeological material and radiocarbon dating). At Crvena Stijena there is a relative paucity of lithic material in the layers immediately above the tephra (Basler, 1975), and this may indicate that use of the cave was not as intensive post-Cl eruption. However, as stated above, archaeological fieldwork and data collection are ongoing as part of renewed investigations at the site, and until the archaeological assemblages have been fully studied it is not possible to establish whether there is a real reduction in intensity of use of the cave, or whether this is due to taphonomic factors or a hiatus in sediment deposition.

More generally, Mihailović (2009) has observed that while the Middle Palaeolithic of the Balkans appears to end around $40 \mathrm{ka}$ in the Adriatic region, there is a dearth of sites in coastal areas with Upper Palaeolithic material that predates about $34 \mathrm{ka}$. On the one hand it could be argued that this apparent gap between the end of the Middle
Palaeolithic and the beginning of the Early Upper Palaeolithic in this region may be the product of an environmental crisis associated with the largest and most widely dispersed volcanic eruption in of the past $200 \mathrm{ka}$ in the Mediterranean (Pyle et al., 2006; Oppenheimer and Pyle, 2009), perhaps compounded by the effects of severe cooling associated with Heinrich Event 4. Alternatively, this gap may simply reflect the lack of well-dated, stratified archaeological sites spanning this period of time allied to our incomplete understanding of the processes involved in the Middle to Upper Palaeolithic transition in this complex region.

\section{Chemical variability of the tephra}

Recent work has highlighted a degree of chemical variability in some exposures of the $\mathrm{CI}$ tephra indicating a well-defined zonation in the pre-eruptive magma chamber (e.g. Ton-That et al., 2001; Pyle et al., 2006; Giaccio et al., 2008). Civetta et al. (1997) suggest that the $\mathrm{Cl}$ eruption produced two chemically distinct volcanic products, with the more highly evolved product reaching as far as the phonolite field. 
Table 4

Late Pleistocene tephras which are thought to have origins in the Campanian volcanic province, southwest Italy.

\begin{tabular}{|c|c|c|c|}
\hline Tephra & Date & Context & References \\
\hline Y3 & ca. 30-31 ka & $\begin{array}{l}\text { Marine, lacustrine and terrestrial } \\
\text { (outcrop) }\end{array}$ & $\begin{array}{l}\text { Keller et al. (1978); Paterne et al. 1986; Narcisi 1996; Munno and Petrosino 2004, 2007; Wulf et al. 2004; } \\
\text { Di Vito et al. 2008; Marciano et al. 2008; Wagner et al. 2008; Zanchetta et al. } 2008\end{array}$ \\
\hline Codola & ca. $33 \mathrm{ka}$ & Marine, lacustrine, terrestrial & Giaccio et al. 2008, and references therein \\
\hline $\mathrm{Y} 5(\mathrm{Cl})$ & ca. 39-41 ka & Marine, lacustrine, cave, peat bog & $\begin{array}{l}\text { Thunell et al. 1979; Vitaliano et al. 1981; Cramp et al. 1989; Vezzoli 1991; Ton-That et al. 2001; } \\
\text { Pyle et al. } 2006\end{array}$ \\
\hline Y7 & $56 \pm 4 \mathrm{ka}$ & Marine, lacustrine & Keller et al. 1978; Kraml 1997; Allen et al. 1999 \\
\hline $\mathrm{X} 2$ & ca. $70 \mathrm{ka}$ & Marine & Vezzoli 1991; Narcisi and Vezzoli 1999; Calanchi and Dinelli 2008 \\
\hline X5 & $105 \pm 2 \mathrm{ka}$ & Marine, lacustrine & Vezzoli 1991; Allen et al. 1999; Calanchi and Dinelli 2008; Marciano et al. 2008 \\
\hline X6 & ca. $110 \mathrm{ka}$ & Marine & Narcisi and Vezzoli 1999; Paterne et al. 2008 \\
\hline
\end{tabular}

There is still some debate as to whether the Codola (33 ka) eruption occurred as part of Somma-Vesuvius or Phlegrean Fields activity.

Figure 7 shows that the Crvena Stijena tephra is dominated by these more chemically evolved materials.

Towards the beginning and end of the eruption less evolved products were ejected, with the more evolved material relating to the upper layer of magma (the final less-evolved layer being related to collapse of the caldera following ejection of the upper layer) (Civetta et al., 1997). It is uncertain at present why such highly evolved products dominate the Crvena Stijena samples, though these differences may be a function of distance from the vent. Giaccio et al. (2008: 211) state that "the presence of a double composition is a peculiar characteristic that constitutes a chemical marker for tracing the CI tephra to very distal settings." Vezzoli (1991) found that the Y5 (CI) tephra, observed in marine cores from Bannock Basin, exhibited chemical heterogeneity with two differently evolved glass populations. He states that "an alkali content up to $12 \%$ leads the most evolved Y-5 L-Na glass to the trachyte/phonolite boundary" (Vezzoli, 1991: 25). If the compositional zonation of the CI eruption could be recognised and quantified in distal tephra deposits, then it could help refine the chronological resolution of the tephra. Crvena Stijena is ideally located being the closest non-Italian mainland exposure of the tephra so far documented and therefore opening up the possibility of identifying the less well-travelled late-phase volcanic material.

The chemical variability of the tephra at Crvena Stijena provides additional support for equivalence with the CI (Giaccio et al., 2008). Indeed, in conjunction with the particle size data, it may indicate that pyroclastic material thought only to have been dispersed over a limited area proximal to the eruption (i.e. mainland Italy) was in fact

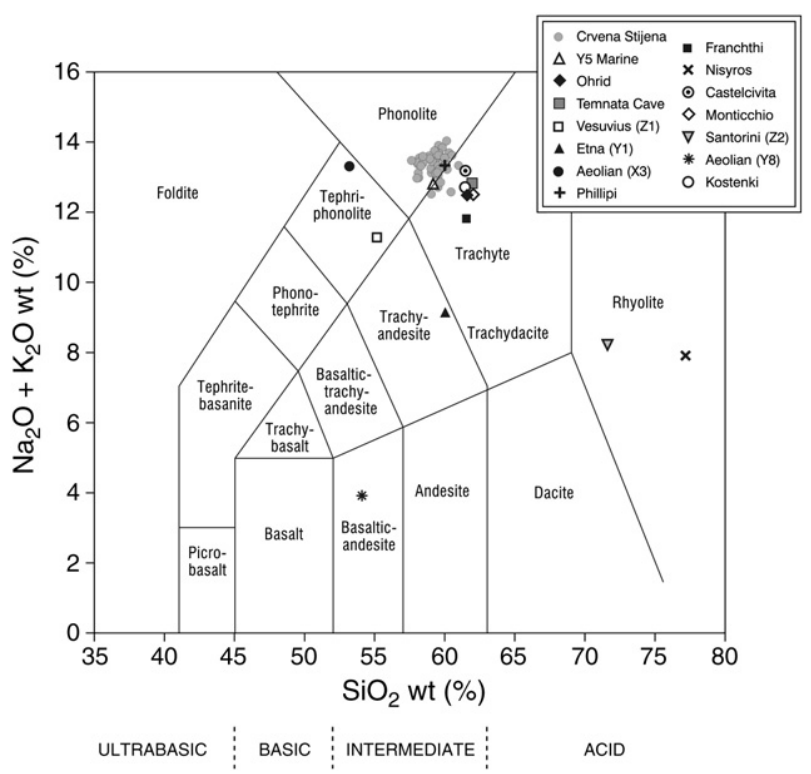

Figure 7. Total-alkali-silica (TAS) plot showing the Crvena Stijena ash compared to published data from sources cited in the text. transported across the Adriatic Sea. The Crvena Stijena ash has retained its coarse component and has a trachytic-phonolitic composition. This may be significant for our understanding of the eruptive history of this event and the areal distribution of successive volcanic ejecta. The high proportion of coarse (fine sand) to fine (coarse silt) material is much less common in sites further from source where the coarser material has been winnowed out.

\section{Some taphonomic issues associated with tephras in caves and rockshelters}

As shown in Fig. 12, rockshelters and caves receive fine-grained sediments from numerous proximal and distal sources and a variety of transport processes can be involved (Woodward and Goldberg, 2001; Courty and Vallverdu, 2001; Kourampas, 2009). At Crvena Stijena, for example, in addition to aeolian inputs, high energy rainfall events can promote the transfer of fine sediments from the external environment into the rockshelter. Fine sediment can enter the rockshelter during such events through conduits and fissures in the shelter walls and ceiling, as water percolates through the host bedrock from the limestone plateau above. Studies have shown that the fine-grained component in limestone rockshelter and cave sediment records is typically overwhelmingly dominated by allogenic (external) materials (Woodward and Bailey, 2000). There is little point in using tephras or other fine-grained sedimentary units as marker horizons if the depositional history and transport pathways of these materials are not fully understood. Site geometry, aspect and geomorphological setting can be key controls on sediment delivery processes and sediment provenance (Woodward and Bailey, 2000). Windblown sediments will enter a site principally through the main opening, but other apertures connected to the external environment may also be important. Following deposition in the site, a number of processes can move sediment particles from their primary depositional context as well as adding new material to dilute and disguise the original phase of deposition. If human use of the site is intensive, fine sediment particles can be mixed (laterally and vertically) with ash and other debris from hearths for example and their original depositional context can be destroyed.

An additional complication in the study of tephra deposits in rockshelters and caves is the likelihood of tephra particles entering such sites for many hundreds, and even thousands, of years after the original phase of tephra fallout on the landscape. The delivery of tephra particles to the rockshelter floor will continue until the external supply of tephra particles from the wider landscape (catchment) becomes exhausted. These later periods of tephra input may involve a series of storage phases on hillslopes and in soil profiles and, typically, much lower concentrations of volcanic material. During such storage and transit stages, tephra particles will become mixed with sediment from more local sources and will typically be associated with much slower rates of delivery (e.g. via infiltration of fine sediments through the karst bedrock) prior to deposition inside a rockshelter or cave environment. Such lag effects in tephra delivery to 

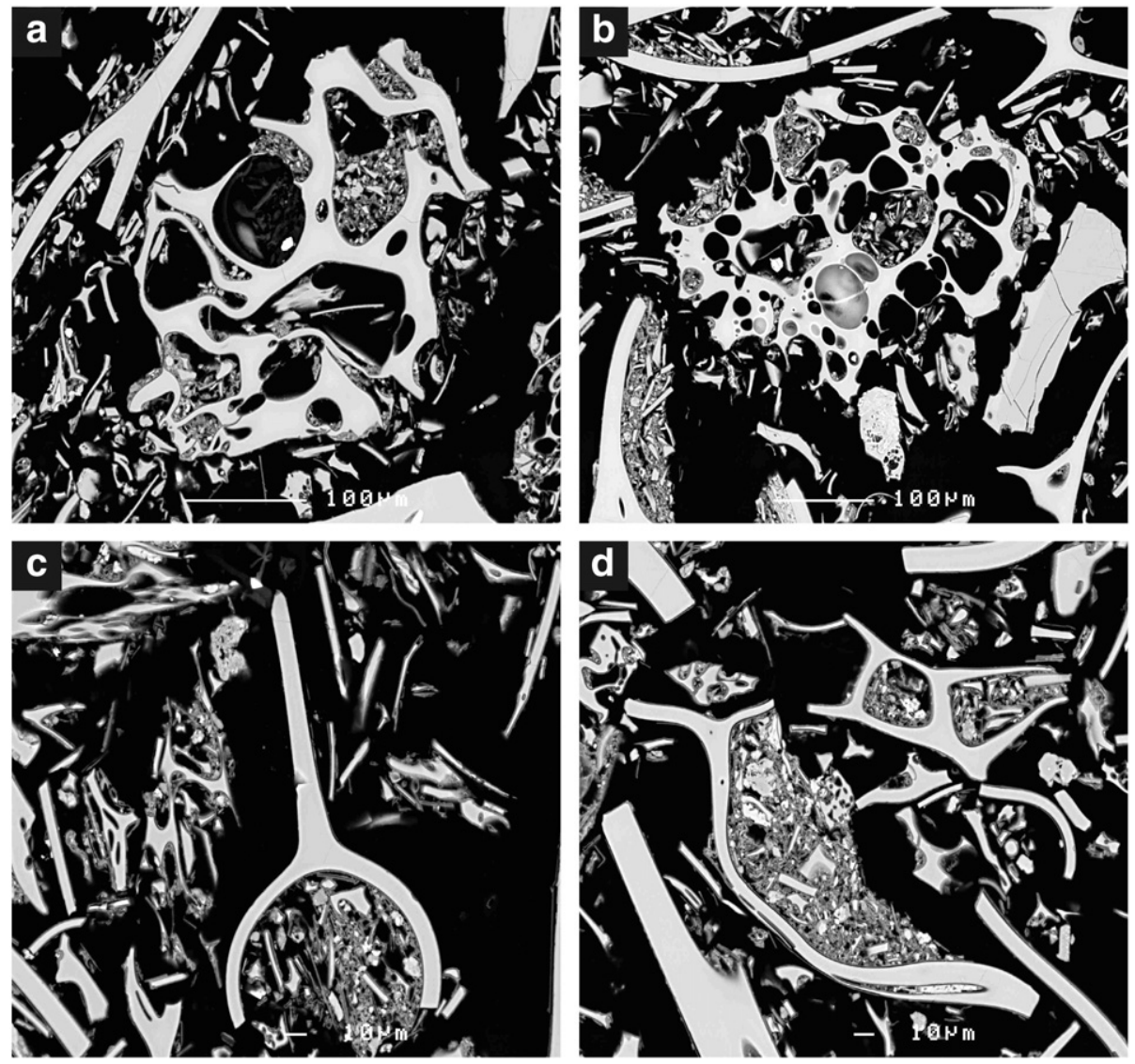

Figure 8. SEM images of tephra shards and pumice grains from Layer XI at Crvena Stijena. Diagnostic characteristics include: a) highly vesicular glass pyroclast with intact spherical vesicles; b) highly vesicular micropumice and elongate tephra shards; c) Y-shaped (tricuspate) tephra shard with adhered dust particles; d) elongate, flat and curved tephra shards, some with intact sub-circular vesicles.

a depositional site have also been observed in lake catchments (Davies et al., 2007 and discussed further below).

If distal volcanic materials are to be used as chronological tools it is imperative to establish if they are in a depositional context that is effectively contemporaneous with the eruption that produced them or if they have been introduced into the site at a much later date. If we assume that a layer of volcanic ash of $c a .5 \mathrm{~cm}$ in thickness was deposited over much of the landscape surrounding Crvena Stijena at the time of the Campanian Ignimbrite eruption, a proportion of this

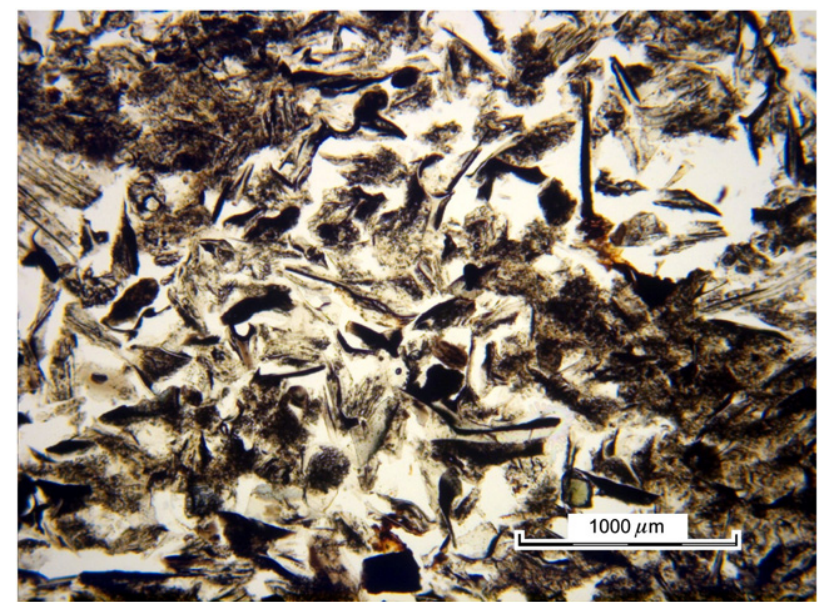

Figure 9. Thin section through Layer XI showing a dense mass of tephra shards and occasional mineral grains. There are no signs of micro-laminae or other bedding features. material is likely to have found its way into the site (along with other allogenic fine sediments) by one or more of the processes shown in Fig. 12 after the deposition of the main tephra (Layer XI) on the rockshelter floor. Two key questions emerge at this point. How much tephra came into the site after the deposition of Layer XI (i.e. during the deposition of Layer X), and for how long? In other words, at which point in the sequence above Layer XI is this contribution no longer discernable in the fine-sediment matrix?

The sedimentary record at Crvena Stijena provides a valuable opportunity to explore some of these issues in a rockshelter sediment record. To this end we have carried out some preliminary qualitative analysis of the metre of deposit above the tephra layer using standard methods and using sediment samples taken at $5 \mathrm{~cm}$ increments. This has shown that volcanic shards are present in the fine sediment matrix of Layer X to a depth of at least 1 metre above the upper surface of Layer $\mathrm{XI}$. The tephra shards in Layer $\mathrm{X}$ are associated with sediments that contain Upper Palaeolithic material (Table 1). While we do not have good dating control for the upper part of these sediments, this exercise has shown that the deposition of tephra shards in rockshelter and cave environments can be associated with significant lag effects and they can be found in association with archaeological materials that are much younger than the age of the eruption that produced them. The shards in the various levels of Layer X are invisible to the naked eye and may be described as cryptotephra (also known as microtephra) (Lowe, 2008). Work is currently in progress to quantify the lag between the deposition of Layer XI and the subsequent transfer of tephra shards from the external environment to the overlying parts of Layer X. It is also important, of course, to be sure that such materials are not associated with later eruptions. This demonstration highlights the need to exercise caution when using small concentrations of distal volcanic shards (i.e. microtephras/cryptotephras) to develop 


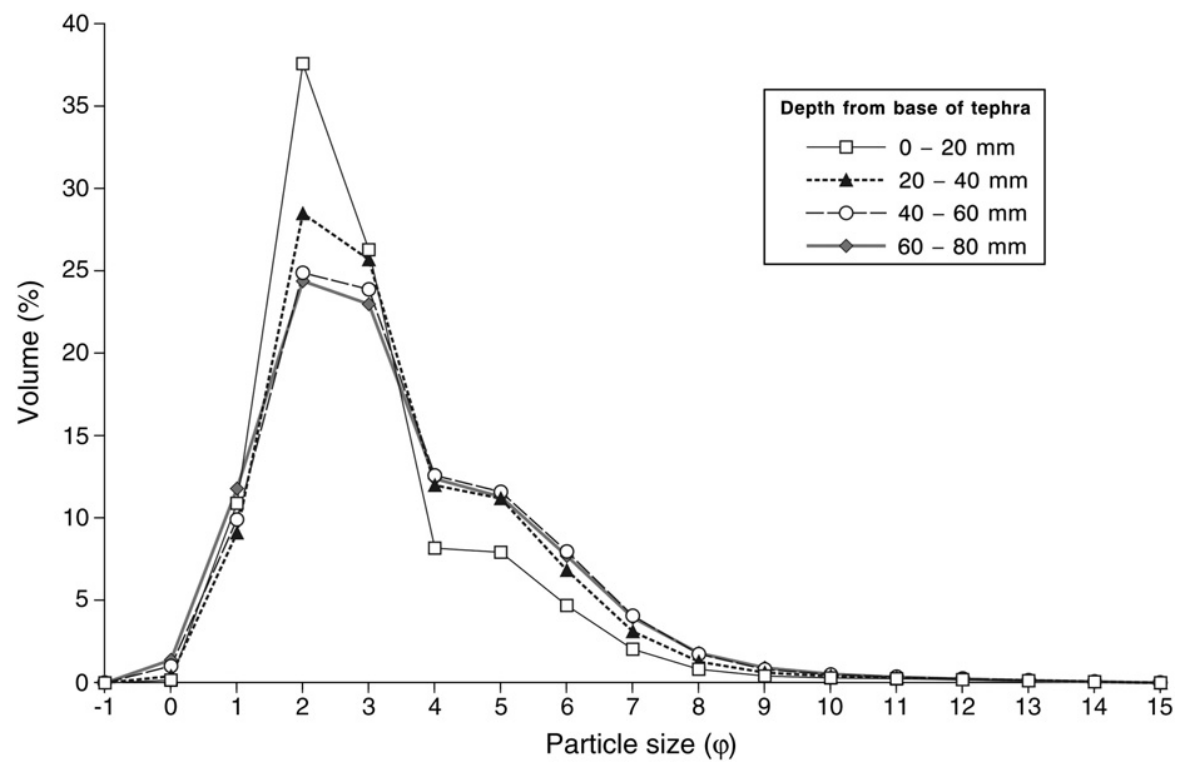

Figure 10. Particle size curves for four samples through Layer XI.

geochronological frameworks for archaeological records in rockshelter and cave mouth environments. These issues have been explored in detail in other contexts.

Davies et al. (2007) provide a detailed analysis of the issues associated with the deposition and identification of cryptotephra horizons in recent lacustrine records. They present high resolution vertical profiles of shard concentrations in two Swedish lakes. Their data show very clearly the importance of catchment processes in controlling the depth profile of shard concentration within the lake sediment record. Significant lag effects in tephra delivery to the lake bottom were identified. They also discuss a diffuse zone of shard concentration below the main cryptotephra peak and they speculate that post-depositional processes may have lead to the downward movement of shards. This work raises a number of issues that need to be carefully considered when attempting to use cryptotephra as time synchronous marker horizons. These issues surrounding the stratigraphic integrity of distal tephras become much more apparent when one considers them in the context of rockshelter and cave sediment records because the resolution of such records is commonly much lower and the potential for post-depositional mixing is high. It is now well-established that distal tephras offer much potential for the correlation of Pleistocene and Holocene records over large geographical areas (Lane et al., 2011), but is it crucial to consider the local geomorphological setting and taphonomic context as well as the resolution of the stratigraphic record under investigation - especially when attempting to extend these correlations to archaeological contexts.

In the same way that peat and lake sediment records were first subjected to high resolution screening for the presence of micro- or crypotephras a couple of decades ago (Lowe, 2008, for a recent review), researchers are now probing ever more carefully into rockshelter and cave sediment records to identify the products of distant eruptions. This will no doubt lead to important revisions to our understanding of the geography and dynamics of tephra dispersal for particular events (Barker et al., 2010). Indeed, caves and rockshelters are attractive in this respect because they can preserve fine-grained sediments that do not survive in the external sub-aerial environment (Woodward and Goldberg, 2001). In some geomorphological settings

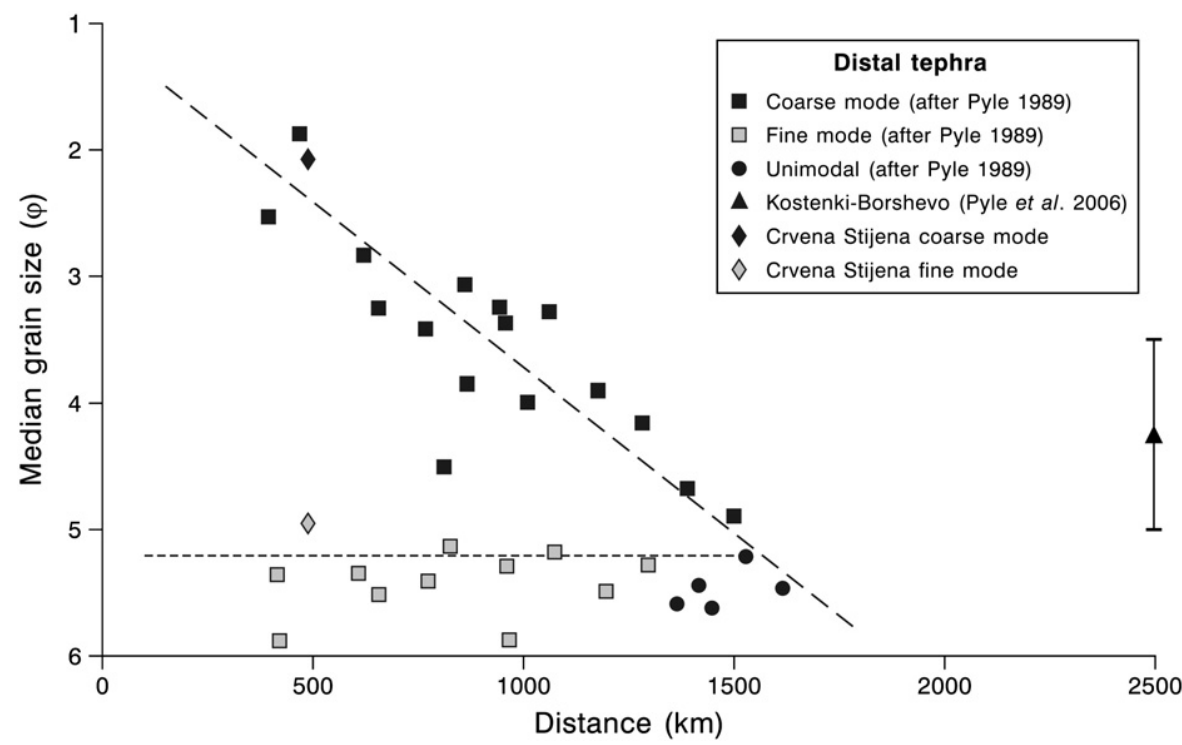

Figure 11. Grain size as a function of distance from source for distal tephra equivalents of the Campanian Ignimbrite (modified from Pyle et al., 2006). See text for discussion. 


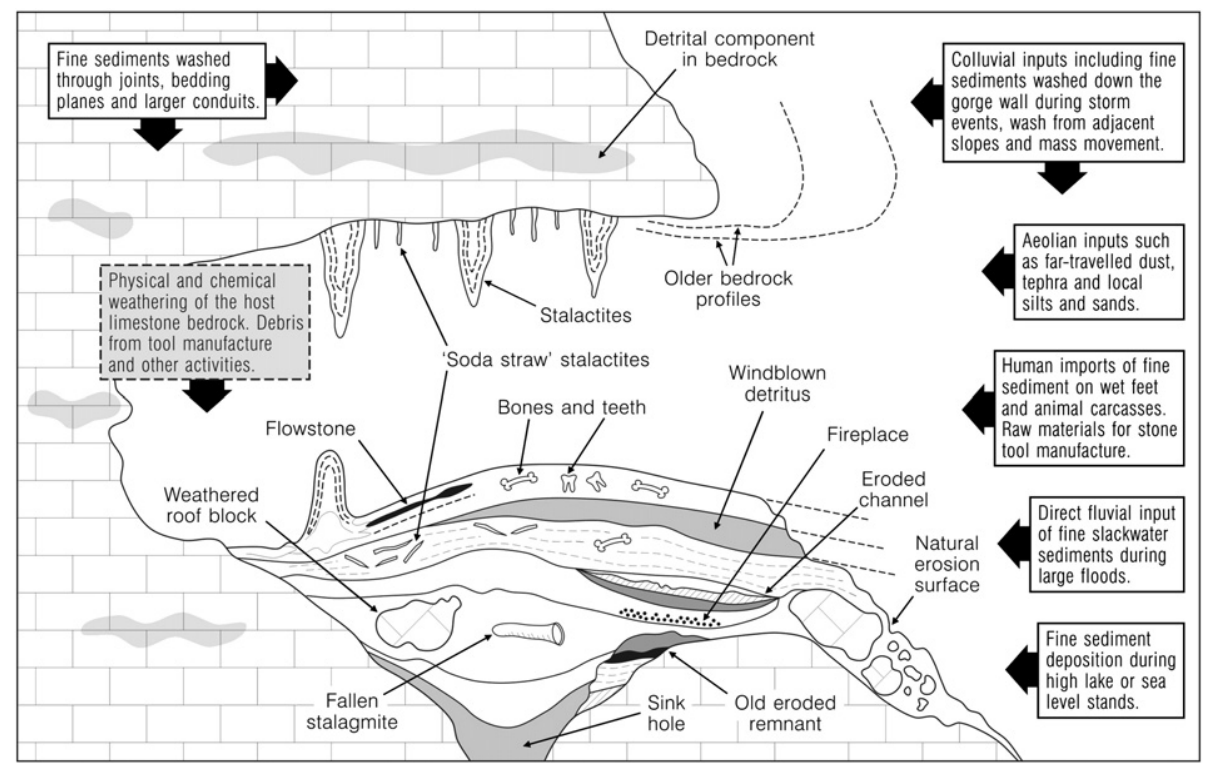

Figure 12. Sediment inputs and related processes in limestone rockshelter and cave mouth environments (after Lewin and Woodward, 2009). Dating methods used in these environments are also shown (after Schwarz and Rink, 2001).

where lake basins are absent, they may provide the only available stratigraphic record of distal tephra deposition. It is important to appreciate, however, that the stratigraphic resolution of the sedimentary records in these environments can be poor (Farrand, 2000), and sediments can be disturbed, dispersed and diluted by a whole gamut of processes-including the actions of humans and animals over many thousands of years.

The nature of the rockshelter floor at the time of tephra input is also a key control on the stratigraphic integrity of distal tephra shards. For example, tephra particles may be washed down into the voids between coarse-grained scree sediments to form part of a fine-grained sediment matrix that is much younger than the host unit formed by limestone clasts. Because thick distal tephra layers are rare in Palaeolithic rockshelters and caves, caution must be exercised in the interpretation of isolated occurrences of distal tephra shards in rockshelter and cave sediment records - especially in cases where small numbers of shards have been recovered from forensic screening of large bulk sediment samples and the origin of the fine sediment fraction is not well constrained. In contexts where the stratigraphic integrity of the tephra particles is difficult to establish, or where they are dispersed through multiple levels, they may have only limited use as chronostratigraphic markers over and above other methods of dating - especially in contexts with complex stratigraphies that lie close to or beyond the range of radiocarbon dating. Importantly, Crvena Stijena is a unique site where these ideas can be carefully tested and this next phase of our work at the site is currently in progress.

\section{Conclusions}

The distal tephra at Crvena Stijena has been correlated to the Campanian Ignimbrite (Y5) eruption through the use of a multi-proxy approach combining a range of sedimentological and geochemical parameters. Micromorphological observations indicate negligible post-depositional reworking of the Crvena Stijena tephra unit (Layer $\mathrm{XI}$ ) following its deposition in the site. Microlaminations or microscale structures indicative of re-mobilisation have not been observed, and significant reworking by water is therefore highly unlikely. A primary context for the Crvena Stijena ash is further supported by the consistent fining-up sequence revealed by detailed particle-size analysis through the tephra layer. The high purity of the tephra deposit and the presence of a small component of rounded non- tephra particles are also indicative of aeolian deposition. The stratigraphical integrity of Layer XI confirms its importance as an independent chronological marker for the archaeological record and it marks the end of Middle Palaeolithic cultures at the site. The Campanian Ignimbrite tephra at Crvena Stijena provides a valuable chronological tie point for the ongoing re-appraisal of the Middle and Upper Palaeolithic assemblages at this site and in the wider region. The sedimentary record also provides an important opportunity to examine some of the potential lag effects involved in the delivery of tephra particles to rockshelter and cave mouth settings so that we can test ideas about the utility of microtephras as chronological tools in these settings.

\section{Acknowledgments}

We would like to thank all those who have worked on the Crvena Stijena project for their help and support. We would especially like to thank Bob Whallon for encouraging the geoarchaeological work at Crvena Stijena. We also thank the following for their help with various laboratory analyses: David Plant, Marie Burguet, John Moore, and David Ashley. Mike Morley thanks the UK Natural Environment Research Council for the provision of a PhD studentship. We also thank Nick Scarle and Graham Bowden (Cartographic Unit, School of Environment and Development, The University of Manchester) for redrafting the figures, and the journal referees, David Pyle and Martin Williams, who provided helpful and constructive reviews.

\section{References}

Accorsi, C.A., Aiello, E., Bartolini, C., Castelletti, L., Rodolfi, G., Ronchitelli, A., 1979. Il giacimento Paleolitico di Serino (Avellino): stratigrafia, 866 ambienti e paletnologia. Atti della Società Toscana di Scienze Naturali, Memorie A 86, 435-487.

Allen, J.R.M., Brandt, U., Brauer, A., Hubberten, H.W., Huntley, B., Keller, J., Kraml, M. Mackensen, A., Mingram, J., Negendank, J.F.W., 1999. Rapid environmental changes in southern Europe during the last glacial period. Nature 400, 740-743.

Anikovich, M.V., Sinitsyn, A.A., Hoffecker, J.F., Holliday, V.T., Popov, V.V., Lisitsyn, S.N. Forman, S.L., Levkovskaya, G.M., Pospelova, G.A., Kuz'mina, I.E., 2007. Early Upper Paleolithic in Eastern Europe and implications for the dispersal of modern humans. Science 315, 223-226.

Baković, M., Mihailović, B., Mihailović, D., Morley, M.W., Vušović-Lučić, Z., Whallon, R., Woodward, J.C., 2009. Crvena Stijena Excavations 2004-2006, preliminary report. Journal of Eurasian Prehistory 6, 3-31.

Barberi, F., Innocenti, F., Lirer, L., Munno, R., Pescatore, T., Santacroce, R., 1978. The Campanian Ignimbrite: a major prehistoric eruption in the Neapolitan area (Italy). Bulletin of Volcanology 41, 10-31. 
Barker, G., Antoniadou, A., Armitage, S., Brooks, I., Candy, I., Connell, K., Douka, K., Drake, N., Farr, L., Hill, E., Hunt, C., Inglish, R., Jones, S., Lane, C., Luccharini, G., Meneely, J., Morales, J., Mutri, G., Prendergast, A., Rabett, R., Reade, H., Reynolds, T., Russell, N., Simpson, D., Smith, B., Stimpson, C., Twati, M., White, K., 2010. The Cyrenaican Prehistory Project 2010: the fourth season of investigations of the Haua Fteah cave and its landscape, and further results from the 2007-2009 fieldwork. Libyan Studies $41,63-88$.

Basler, D. (Ed.), 1975. Crvena Stijena: Zbornik radova. Zajednica Kulturnih Ustanova, Nikšić.

Beer, J., Muscheler, R., Wagner, G., Laj, C., Kissel, C., Kubik, P.W., Synal, H.-A., 2002. Cosmogenic nuclides during Isotope Stages 2 and 3. Quaternary Science Reviews $21,1129-1139$

Blockley, S.P.E., Bronk Ramsey, C., Higham, T.F.G., 2008. The Middle to Upper Palaeolithic transition: dating, stratigraphy, and isochronous markers. Journal of Human Evolution 55, 764-771.

Brunnacker, K., 1975. Die Sedimente der Crvena Stijena. In: Basler, Đ. (Ed.), Crvena Stijena: Zbornik Radova. Zajednica Kulturnih Ustanova, Nikšić, pp. 171-203.

Bullock, P., Federoff, N., Jongerius, A., Stoops, G., Tursina, T., Babel, U., 1985. Handbook for Soil Thin Section Description. Waine Research Publications, Wolverhampton.

Calanchi, N., Dinelli, E., 2008. Tephrostratigraphy of the last $170 \mathrm{ka}$ in sedimentary successions from the Adriatic Sea. Journal of Volcanology and Geothermal Research $177,81-95$.

Civetta, L., Orsi, G., Pappalardo, L., Fisher, R.V., Heiken, G., Ort, M., 1997. Geochemical zoning, mingling, eruptive dynamics and depositional processes-the Campanian Ignimbrite, Campi Flegrei caldera, Italy. Journal of Volcanology and Geothermal Research 75, 183-219.

Conard, N.J. (Ed.), 2006. When Neanderthals and Modern Humans Met. Tübingen Publications in Prehistory, Kerns Verlag, Tübingen.

Conard, N.J., Bolus, M., 2008. Radiocarbon dating the late Middle Paleolithic and the Aurignacian of the Swabian Jura. Journal of Human Evolution 55, 886-897.

Courty, M.-A., Vallverdu, J., 2001. The microstratigraphic record of abrupt climate changes in cave sediments of the Western Mediterranean. Geoarchaeology: An International Journal 16, 467-499.

Cramp, A., Vitaliano, C.J., Collins, M.B., 1989. Identification and dispersion of the Campanian ash layer (Y-5) in the sediments of the Eastern Mediterranean. GeoMarine Letters 9, 19-25.

De Vivo, B., Rolandi, G., Gans, P.B., Calvert, A., Bohrson, W.A., Spera, F.J., Belkin, H.E., 2001. New constraints on the pyroclastic eruptive history of the Campanian volcanic Plain (Italy). Mineralogy and Petrology 73, 47-65.

Davies, S.M., Elmquist, M., Bergman, J., Wohlfarth, B., Hammarlund, D., 2007. Cryptotephra sedimentation processes within two lacustrine sequences from west central Sweden. Holocene 17, 319-330.

Dennell, R., 2003. Dispersal and colonisation, long and short chronologies: how continuous is the Early Pleistocene record for hominids outside East Africa? Journal of Human Evolution 45, 421-440.

Di Vito, M.A., Sulpizio, R., Zanchetta, G., D'Orazio, M., 2008. The late Pleistocene pyroclastic deposits of the Campanian Plain: New insights into the explosive activity of Neapolitan volcanoes. Journal of Volcanology and Geothermal Research 177, 19-48.

Farrand, W.R., 2000. Depositional history of Franchthi Cave: Stratigraphy, Sedimentology, and Chronology. Indiana University Press, Indiana.

Fedele, F.G., Giaccio, B., Hajdas, I., 2008. Timescales and cultural process at 40, $000 \mathrm{BP}$ in the light of the Campanian Ignimbrite eruption, Western Eurasia. Journal of Human Evolution 55, 834-857.

Fedele, F.G., 2002. Ecosystem impact of the Campanian ignimbrite eruption in Late Pleistocene Europe. Quaternary Research 57, 420-424.

Fedele, F.G., Giaccio, B., Isaia, R., Orsi, G., 2003. The Campanian Ignimbrite eruption, Heinrich Event 4, and Palaeolithic change in Europe: a high-resolution investigation. Geophysical monograph 139, 301-325.

Fedele, F.G., Giaccio, B., Isaia, R., Orsi, G., Carroll, M., Scaillet, B., 2007. The Campanian Ignimbrite factor: towards a reappraisal of the Middle to Upper Palaeolithic 'transition'. In: Grattan, J., Torrence, R. (Eds.), Living Under the Shadow: the Cultural Impacts of Volcanic Eruptions, One World Archaeology vol. 53. Left Coast Press, California, pp. 19-41.

Finlayson, C., Pacheco, F.G., Rodríguez-Vidal, J., Fa, D.A., López, J.M.G., Pérez, A.S., Finlayson, G., Allue, E., Preysler, J.B., Cáceres, I., 2006. Late survival of Neanderthals at the southernmost extreme of Europe. Nature 443, 850-853.

Fumanal, M.P., 1997. La Cueva de Castelcivita. Estudio sedimentológico. In: Gambassini, P. (Ed.), Il Paleolitico di Castelcivita, culture e ambiente. Napoli, Electa Napoli, pp. 19-32.

Gamble, C., 1999. The Palaeolithic Societies of Europe. Cambridge University Press, Cambridge.

Giaccio, B., Hajdas, I., Peresani, M., Fedele, F.G., Isaia, R., 2006. The Campanian Ignimbrite and its relevance for the timing of the Middle to Upper Palaeolithic shift. In: Conard, N.J. (Ed.), When Neanderthals and Modern Humans Met. Tübingen Publications in Prehistory, Kerns Verlag, Tübingen, pp. 343-375.

Giaccio, B., Isaia, R., Fedele, F.G., Di Canzio, E., Hoffecker, J., Ronchitelli, A., Sinitsyn, A.A., Anikovich, M., Lisitsyn, S.N., Popov, V.V., 2008. The Campanian Ignimbrite and Codola tephra layers: Two temporal/stratigraphic markers for the Early Upper Palaeolithic in southern Italy and Eastern Europe. Journal of Volcanology and Geothermal Research 177, 208-226.

Guillou, H., Singer, B.S., Laj, C., Kissel, C., Scaillet, S., Jicha, B.R., 2004. On the age of the Laschamp geomagnetic excursion. Earth and Planetary Science Letters 227, 331-343.

Hoffecker, J.F., Holliday, V.T., Anikovich, M.V., Sinitsyn, A.A., Popov, V.V., Lisitsyn, S.N., Levkovskaya, G.M., Pospelova, G.A., Forman, S.L., Giaccio, B., 2008. From the Bay of Naples to the River Don: the Campanian Ignimbrite eruption and the Middle to
Upper Paleolithic transition in Eastern Europe. Journal of Human Evolution 55, 858-870.

Hughen, K., Lehman, S., Southon, J., Overpeck, J., Marchal, O., Herring, C., Turnbull, J., 2004. $14 \mathrm{C}$ activity and global carbon cycle changes over the past 50, 000 years. Science 303, 202-207.

Hughes, P.D., Woodward, J.C., 2009. Glacial and Periglacial Environments. In: Woodward, J.C. (Ed.), The Physical Geography of the Mediterranean. Oxford University Press, pp. 353-383.

Hughes, P.D., Woodward, J.C., van Calsteren, P.C., Thomas, L.E., Adamson, K., 2010. Pleistocene ice caps on the coastal mountains of the Adriatic Sea. Quaternary Science Reviews 29, 3690-3708.

Jöris, O., Fernandez, E.A., Weninger, B., 2003. Radiocarbon evidence of the Middle to Upper Palaeolithic transition in southwestern Europe. Trabajos de Prehistoria 60, $15-38$.

Jöris, O., Street, M., 2008. At the end of the ${ }^{14} \mathrm{C}$ time scale-the Middle to Upper Paleolithic record of western Eurasia. Journal of Human Evolution 55, 782-802.

Karavanic, I., Smith, F.H., 2000. More on the Neanderthal problem: The Vindija case. Current Anthropology 41, 838-840.

Keller, J., Ryan, W.B.F., Ninkovich, D., Altherr, R., 1978. Explosive volcanic activity in the Mediterranean over the past 200,000 yr as recorded in deep-sea sediments. Bulletin of the Geological Society of America 89, 591-604

Kourampas, N., Simpson, I.A., Perera, N., Deraniyagala, S.U., Wijeyapala, W.H., 2009. Rockshelter sedimentation in a dynamic tropical landscape: Late Pleistocene-Early Holocene archaeological deposits in Kitulgala Beli-lena, southwestern Sri Lanka. Geoarchaeology 24, 677-714.

Kozlowski, J.K., 2006. Early Human Migrations: Incipient Stages of Old World Peopling. Diogenes 211, 9-22.

Kozlowski, J.K., 1998. The Middle and the early Upper Paleolithic around the Black Sea In: Akazawa, T., Aoki, K., Bar Yosef, O. (Eds.), Neanderthals and Modern Humans in Western Asia. Plenum Press, New York, pp. 461-482.

Kozlowski, J.K., Laville, H., Ginter, B., 1992. Temnata cave: excavations in Karlukovo Karst Area. Jagiellonian University, Kraków, Bulgaria.

Laser-40 Ar/39 Ar-Datierungen an distalen marinen Tephren des jung-quartären Mediterranen Vulkanismus (Ionisches Meer, METEOR-Fahrt 25/4). Dissertation Universität Freiburg

Lane, C.S., Blockley, S.P.E., Lotter, A.F., Finsinger, W., Filippi, M.L., Matthews, I.P., 2011. A regional tephrostratigraphic framework for central and southern European climate archives during the Last Glacial to Interglacial Transition: comparisons north and south of the Alps. Quaternary Science Reviews (in press).

Le Bas, M.J., Le Maitre, R.W., Streckeisen, A., Zanettin, B., 1986. A chemical classification of volcanic rocks based on the total alkali-silica diagram. Journal of Petrology 27, $745-750$.

Lewin, J., Woodward, J.C., 2009. Karst geomorphology and environmental change. In: Woodward, J.C. (Ed.), The Physical Geography of the Mediterranean. Oxford University Press, pp. 287-317.

Lowe, J.J., Blockley, S., Trincardi, F., Asioli, A., Cattaneo, A., Matthews, I.P., Pollard, M., Wulf, S., 2007. Age modelling of late Quaternary marine sequences in the Adriatic: Towards improved precision and accuracy using volcanic event stratigraphy. Continental Shelf Research 27, 560-582.

Lowe, D.J., 2008. Globalization of tephrochronology: new views from Australasia. Progress in Physical Geography 32, 311-335.

Lund, S.P., Schwartz, M., Keigwin, L., Johnson, T., 2005. Deep-sea sediment records of the Laschamp geomagnetic field excursion (c. 41, 000 calendar years before present). Journal of Geophysical Research 110, B04101.

Marciano, R., Munno, R., Petrosino, P., Santangelo, N., Santo, A., Villa, I., 2008. Late Quaternary tephra layers along the Cilento coastline (southern Italy). Journal of Volcanology and Geothermal Research 177, 227-243.

Margari, V., Pyle, D.M., Bryant, C., Gibbard, P., 2007. Mediterranean tephra stratigraphy revisited: results from a long terrestrial sequence from Lesvos Island, Greece. Journal of Volcanology and Geothermal Research 163, 34-54.

Matarazzo, T., Berna, F., Goldberg, P., 2010. Occupation surfaces sealed by the Avellino eruption of Vesuvius at the Early Bronze Age village of Afragola in southern Italy: A micromorphological analysis. Geoarchaeology 25, 437-466.

Mazaud, A., Laj, C., Bard, E., Arnold, M., Tric, E., 1991. Geomagnetic field control of 14 C production over the last $80 \mathrm{ky}$ : implications for the radiocarbon time-scale. Geophysical Research Letters 18, 1885-1888.

Mellars, P., 2004. Neanderthals and the modern human colonization of Europe. Nature $432,461-465$

Morley, M.W., 2007. Mediterranean Quaternary Rockshelter Sediment Records: A Multi-Proxy Approach to Environmental Reconstruction. University of Manchester Unpublished $\mathrm{PhD}$ Thesis.

Munno, R., Petrosino, P., 2004. New constraints on the occurrence of Y-3 Uppe Pleistocene tephra marker layer in the Tyrrhenian Sea. Quaternario 17, 11-20.

Munno, R., Petrosino, P., 2007. The late Quaternary tephrostratigraphical record of the San Gregorio Magno basin (southern Italy). Journal of Quaternary Science 22, 247-266.

Narcisi, B., Vezzoli, L., 1999. Quaternary stratigraphy of distal tephra layers in the Mediterranean-an overview. Global and Planetary Change 21, 31-50.

Oppenheimer, C., Pyle, D.M., 2009. Volcanoes. In: Woodward, J.C. (Ed.), The Physical Geography of the Mediterranean. Oxford University Press, Oxford, pp. 435-468.

Palma di Cesnola, A., 2006. Aurignacian and early Gravettian of Paglicci cave-Mount Gargano. L'Anthropologie 110, 355-370.

Paterne, M., Kallel, N., Labeyrie, L., Vautravers, M., Duplessy, J.C., Rossignol-Strick, M., Cortijo, E., Arnold, M., Fontugne, M., 1999. Hydrological relationship between the North Atlantic Ocean and the Mediterranean Sea during the past 15-75 kyr. Paleoceanography 14, 626-638. 
Paterne, M., Guichard, F., Duplessy, J.C., Siani, G., Sulpizio, R., Labeyrie, J., 2008. A $90,000-200,000$ yrs marine tephra record of Italian volcanic activity in the Central Mediterranean Sea. Journal of Volcanology and Geothermal Research 177 187-196.

Pawlikowski, M., 1992. Analysis of tephra layers from TD-II and TD-V excavations. In: Kozlowski, J.K. Laville, H., Ginter, B. (Eds.), Excavations in Karlukovo Karst Area, Bulgaria, Stratigraphy and environment. Archaeology of Gravettian layers, Vol.1, pt.1. Jagiellonian University, Kraków, pp. 89-98.

Pettitt, P.B., Davies, W., Gamble, C.S., Richards, M.B., 2003. Palaeolithic radiocarbon chronology: quantifying our confidence beyond two half-lives. Journal of Archaeological Science 30, 1685-1693.

Pyle, D.M., 1989. The thickness, volume and grainsize of tephra fall deposits. Bulletin of Volcanology 51, 1-15.

Pyle, D.M., Ricketts, G.D., Margari, V., Van Andel, T.H., Sinitsyn, A.A., Praslov, N.D. Lisitsyn, S., 2006. Wide dispersal and deposition of distal tephra during the Pleistocene ‘Campanian Ignimbrite/Y5' eruption, Italy. Quaternary Science Reviews $25,2713-2728$.

Roebroeks, W., 2008. Time for the Middle to Upper Paleolithic transition in Europe. Journal of Human Evolution 55, 918-926.

Rosi, M., Vezzoli, L., Castelmenzano, A., Grieco, G., 1999. Plinian pumice fall deposit of the Campanian Ignimbrite eruption (Phlegraean Fields, Italy). Journal of Volcanology and Geothermal Research 91, 179-198.

Santacroce, R., Cioni, R., Marianelli, P., Sbrana, A., Sulpizio, R., Zanchetta, G., Donahue, D.J., Joron, J.L., 2008. Age and whole rock-glass compositions of proximal pyroclastics from the major explosive eruptions of Somma-Vesuvius: a review as a tool for distal tephrostratigraphy. Journal of Volcanology and Geothermal Research 177, 1-18.

Schwarz, H.P., Rink, W.J., 2001. Dating methods for sediments of caves and rockshelters. Geoarchaeology: An International Journal 16, 355-371.

Self, S., 2006. The effects and consequences of very large explosive volcanic eruptions. Philosophical Transactions of the Royal Society A 364, 2073-2097.

Sinitsyn, A.A., Hoffecker, J.F., 2006. Radiocarbon dating and chronology of the Early Upper Paleolithic at Kostenki. Quaternary International 152, 164-174.

Sparks, S., Self, S., Grattan, J., Oppenheimer, C., Pyle, D., Rymer, H., 2005. Supereruptions: global effects and future threats. Report of a Geological Society of London Working Group. Geological Society of London, second (print) edition.

Stoops, G., 2003. Guidelines for analysis and description of soil and regolith thin sections. Soil Science Society of America, Madison, WI.

St Seymour, K.S., Christanis, K., 1995. Correlation of a tephra layer in Western Greece with a Late Pleistocene eruption in the Campanian province, Italy. Quaternary Research 43, 45-54.

St Seymour, K.S., Christanis, K., Bouzinos, A., Papazisimou, S., Papatheodorou, G. Moran, E., Dénès, G., 2004. Tephrostratigraphy and tephrochronology in the Philippi peat basin, Macedonia, Northern Hellas (Greece). Quaternary International 121, 53-65.
Thunell, R., Federman, A., Sparks, S., Williams, D., 1979. The age, origin, and volcanological significance of the Y-5 ash layers in the Mediterranean. Quaternary Research 12, 241-253.

Ton-That, T., Singer, B., Paterne, M., 2001. 40Ar/39Ar dating of latest Pleistocene (41 ka) marine tephra in the Mediterranean Sea: implications for global climate records. Earth and Planetary Science Letters 184, 645-658.

Van Andel, T., Davies, W., 2004. Neanderthals and modern humans in the European landscape during the last glaciation. McDonald Institute Monograph, Cambridge.

Vezzoli, L., 1991. Tephra layers in Bannock basin (eastern Mediterranean). Marine Geology 100, 21-34.

Vinci, A., 1985. Distribution and chemical composition of tephra layers from eastern Mediterranean abyssal sediments. Marine Geology 64, 143-155.

Vitaliano, C.J., Taylor, S.R., Farrand, W.R., Jacobsen, T.W., 1981. Tephra layer in Franchthi cave, Peloponnesos, Greece. In: Self, S., Sparks, R.S.J. (Eds.), Tephra Studies, Nato Advanced Study Institutes Series, C 75. Reidel, Dordrecht, pp. 373-379.

Voelker, A.H.L., Grootes, P.M., Nadeau, M.J., Sarntheim, M., 2000. Radiocarbon levels in the Iceland Sea from $25-53 \mathrm{kyr}$ and their link to the earth's magnetic field intensity. Radiocarbon 42, 437-452.

Wagner, B., Sulpizio, R., Zanchetta, G., Wulf, S., Wessels, M., Daut, G., Nowaczyk, N., 2008. The last $40 \mathrm{ka}$ tephrostratigraphic record of Lake Ohrid, Albania and Macedonia: a very distal archive for ash dispersal from Italian volcanoes. Journal of Volcanology and Geothermal Research 177, 71-80.

Woodward, J.C., Bailey, G.N., 2000. Sediment sources and terminal Pleistocene geomorphological processes recorded in rockshelter sequences in Northwest Greece. In: Foster, I.D.L. (Ed.), Tracers in geomorphology. Wiley, Chichester, pp. 521-551.

Woodward, J.C., Goldberg, P., 2001. The sedimentary records in Mediterranean rockshelters and caves: Archives of environmental change. Geoarchaeology 16 327-354.

Woodward, J.C., Hamlin, R.H.B., Macklin, M.G., Karkanas, P., Kotjabopoulou, E., 2001. Quantitative sourcing of slackwater deposits at Boila rockshelter: A record of lateglacial flooding and Palaeolithic settlement in the Pindus Mountains, northern Greece. Geoarchaeology: An International Journal 16, 501-536.

Wulf, S., Kraml, M., Brauer, A., Keller, J., Negendank, J.F.W., 2004. Tephrochronology of the $100 \mathrm{ka}$ lacustrine sediment record of Lago Grande di Monticchio (southern Italy). Quaternary International 122, 7-30.

Zanchetta, G., Sulpizio, R., Giaccio, B., Siani, G., Paterne, M., Wulf, S., D'Orazio, M., 2008. The Y-3 tephra: A Last Glacial stratigraphic marker for the central Mediterranean basin. Journal of Volcanology and Geothermal Research 177, 145-154.

Zielinski, G.A., Mayewski, P.A., Meeker, L.D., Grönvold, K., Germani, M.S., Whitlow, S., Twickler, M.S., Taylor, K., 1997. Volcanic aerosol records and tephrochronology of the Summit, Greenland, ice cores. Journal of Geophysical Research-Oceans 102 , $26,625-26,640$

Zielinski, G.A., Mayewski, P.A., Meeker, L.D., Whitlow, S., Twickler, M.S., 1996. A 110 000 -yr record of explosive volcanism from the GISP2 (Greenland) ice core. Quaternary Research 45, 109-118. 